\title{
Younger Dryas Glaciers and climate in the Mourne Mountains, Northern Ireland
}

\author{
Iestyn, D. Barr ${ }^{\mathrm{a} *}$, Sam Roberson ${ }^{\mathrm{b}}$, Rory Flood ${ }^{\mathrm{c}}$, Jason Dortch ${ }^{\mathrm{d}}$ \\ aSchool of Natural and Built Environment, Queen's University Belfast, BT7 1NN, UK \\ ${ }^{\mathrm{b}}$ Geological Survey of Northern Ireland, Dundonald House, Upper Newtownards Rd, Belfast, \\ BT4 3SB, UK

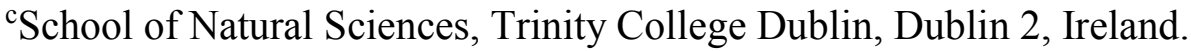 \\ ${ }^{\mathrm{d}}$ Department of Geography, University of Manchester, Oxford Road, Manchester, M13 9PL, \\ UK
}

*Corresponding author

Address: School of Natural and Built Environment, Queen's University Belfast, BT7 1NN, UK

Email: i.barr@qub.ac.uk

Tel: +44(0)2890975146

\section{Keywords:}

Northern Ireland,

Younger Dryas,

Glacier,

Climate,

Schmidt Hammer

\begin{abstract}
Here, we present evidence to suggest that the Mourne Mountains, Northern Ireland, were last occupied by glaciers during the Younger Dryas Stadial. The margins of these glaciers are marked by moraines, chronologically constrained to the Younger Dryas by Schmidt Hammer exposure dating. Reconstructions indicate that these glaciers had equilibrium-line altitudes (ELAs) ranging from $356 \pm 33 \mathrm{~m}$ (a.s.1.) to $570 \pm 9 \mathrm{~m}$ (a.s.l.), with a mean of $475 \pm 36 \mathrm{~m}$ (a.s.l.). ELAs rise from west to east, likely reflecting the contribution of windblown snow and ice to the accumulation of Younger Dryas glaciers in the western Mournes. Taking this into consideration, a mean 'climatic' ELA of $529 \pm 4 \mathrm{~m}$ (a.s.1.) is calculated for the mountains as a whole. Assuming a mean annual sea level air temperature of $-8^{\circ} \mathrm{C}$, and an annual temperature range of $34^{\circ} \mathrm{C}$, degree-day modelling suggests that during the Younger Dryas, accumulation at the 'climatic' ELA of glaciers in the Mournes was $846-990 \mathrm{~mm} \mathrm{a}^{-1}$. This suggests increased aridity, relative to present, and is consistent with other parts of NW Europe, where reduced precipitation, alongside notable cooling is thought to reflect increased North Atlantic sea ice extent during the Younger Dryas.
\end{abstract}

\section{Introduction}

During the Younger Dryas Stadial (known in Ireland as the Nahanagan Stadial), equivalent to Greenland Stadial-1 (GS-1; c. 12.9-11.7 ka) (Lowe et al., 2008), ice masses developed in many mountain ranges in NW Europe in response to rapid climatic cooling during the final stages of deglaciation from the Last Glacial Maximum (LGM) (Fairbanks, 1990; Renssen et al., 2015). In many parts of Scotland, Wales, England, and Ireland, the extent of these glaciers, and the climate that allowed their formation, has been the focus of considerable study (e.g., Harrison et al., 2010; Bendle and Glasser, 2012; Boston et al., 2015). However, in Northern Ireland, though there is palaeoenvironmental evidence for cooling (e.g., Watson et al., 2010; Walker et $a l ., 2012$ ), climatic conditions and the extent of glaciers during the Younger Dryas remain 
poorly understood (see Wilson 2004a,b; Rea and McCarron, 2008). One location where glaciers are presumed to have developed is in the Mourne Mountains (hereafter 'the Mournes') (Fig. 1), where geomorphological evidence suggests the former presence of small ice masses (Sutton, 1998; Wilson, 2004a). Analysing these former glaciers has important implications for understanding local and regional palaeoclimate, since the Mournes are located between the mountains of Scotland, NW England, North Wales, and western and eastern Ireland, where glacier-based climate reconstructions for the Younger Dryas have been generated (Ballantyne et al., 2008; Golledge, 2010; Golledge et al., 2010; Harrison et al., 2010; Bendle and Glasser, 2012; Brown et al., 2013). Given this significance, the purpose of this paper is to investigate the extent of glaciers in the Mournes during the Younger Dryas, and to reconstruct the climatic conditions under which they formed.

\section{Study area and glacial history}

The Mournes are located in NE Ireland, bordering the Irish Sea Basin (Fig. 1), they cover $150 \mathrm{~km}^{2}$, and reach a maximum altitude (Slieve Donard) of $850 \mathrm{~m}$ above sea level (a.s.1.). The mountains are primarily composed of a granite complex that was intruded into Silurian greywacke and slate country rock c. $56 \mathrm{Ma}$ (Cooper and Johnston, 2004) (Fig. 1B), and have undergone multiple phases of glaciation during the Quaternary (see Dwerryhouse, 1923; Charlesworth, 1938; Stephens et al., 1975; Gellatly, 1985; Sutton, 1998). At the LGM, known locally as the Glenavy Stadial (Bazley, 2004), the mountains were entirely submerged by the British Irish Ice Sheet (BIIS) which reached its maximum areal extent c. 27 ka (Clark et al., 2012). Following the LGM, the deglaciation of the coast of NE Ireland likely occurred sometime before $18.2 \mathrm{ka}$ (during the Cooley Point Interstadial) (McCabe et al., 2007), when the BIIS retreated north and NW, away from the Mournes. This was followed by a period of ice sheet readvance, during the Clogher Head Stadial (c. 18.2-17.4 ka); retreat during the Linns Interstadial (c. $17.4 \mathrm{ka}$ ); before a final readvance during the Killard Point Stadial (c. 17.2-16.6 ka) (age estimates based on McCabe et al., 2007, calibrated by Clark et al., 2012). During these phases of readvance, the ice sheet moved south, but was deflected by the Mournes, and flowed east and west around their margins, with tongues of ice extending from North to South through the mountains. Following the Killard Point Stadial, the ice sheet retreated north and, despite later readvances, never again reached the Mournes (see McCabe and Clark, 1998; McCabe and Williams, 2012). Mountain glaciers are generally considered to have last occupied the Mournes during the Younger Drays Stadial (Sutton, 1998; Wilson, 2004a), as in other parts of Ireland (Colhoun and Synge, 1980; Anderson et al., 1998; Harrison et al., 2010) and Britain (Ballantyne, 2007a,b; Golledge, 2010; Bendle and Glasser, 2012), though no detailed analysis of the dimensions of these glaciers has been conducted (c.f. Sutton, 1998).

\section{Methods}

\section{Geomorphological mapping}

In order to establish the former extent of glaciers in the Mournes, the region's glacial geomorphology was mapped from Bing aerial photographs and during field-based investigations. Though there are a number geomorphological indicators of former glaciation in the region, including erratic boulders, striations, glacially-smoothed bedrock surfaces, and roche moutonnée (Sutton, 1998; Wilson, 2004a), our focus was primarily on mapping moraines (though cirques were also mapped), on the grounds that they are the best geomorphological indicators of the dimensions of former mountain glaciers. Mapping was guided by Sutton (1998), and restricted to moraines within, or emanating from, the mountains, rather than considering the large and conspicuous moraines, which reflect former ice sheet extent, on adjacent lowlands (see Sutton, 1998; McCabe and Dunlop, 2006). 


\section{Establishing a glacial chronology}

To establish a chronology for former glaciation in the Mournes, ideally a robust cosmogenic chronology would be established. However, to our knowledge, there are no published numerical ages to constrain the chronology of former glaciation in the mountains, and moraines are difficult to group morphostratigraphically (c.f. Lukas, 2006). In the absence of these data, Schmidt hammer exposure dating (SHED) was used in the present investigation. SHED is a long established technique for obtaining a relative chronology for surface exposure (Matthews and Shakesby, 1984), and has been widely applied to glacial environments (Goudie, 2006; Tomkins et al., 2016). The principal of the method is that the Schmidt hammer is applied to a rock surface, and a rebound value $(\mathrm{R})$ recorded. This $\mathrm{R}$-value is considered a measure of rock strength - with stronger/harder surfaces returning higher R-values (Aydin and Basu, 2005). In formerly glaciated environments it is assumed that surfaces that have been glacierfree (i.e., exposed) for long periods will have experienced considerable weathering, and will therefore be 'softer', and return lower R-values, than more recently deglaciated areas. As a result, the procedure can be a simple and rapid way of establishing a relative chronology of deglaciation.

To obtain numerical age estimates using the technique requires independent dating control to generate R-value calibration curves (i.e., to convert R-values to numerical ages) (see Winkler, 2009; Matthews and Owen, 2010). Recently, Tomkins et al. (2016) produced a series of R-value calibration curves by sampling 76 surfaces in the UK, dated using Beryllium-10 $\left({ }^{10} \mathrm{Be}\right)$ Terrestrial Cosmogenic Nuclide Dating (TCND). Tomkins et al. (2016) produced individual curves for different lithologies, but found that granite surfaces alone demonstrate a statistically significant relationship between exposure age and R-values (see Fig. 2). In the present study, this calibration curve (Fig. 2) was used to establish a chronology of deglaciation in the Mournes. To allow direct comparison with their calibration curve, sampling procedures followed Tomkins et al. (2016). R-value measurements were taken using a Proceq ${ }^{\mathrm{TM}}$ ' $\mathrm{N}$ ' type Schmidt Hammer. Sampling was restricted to horizontal (or near horizontal), dry surfaces on large boulders ( $>1 \mathrm{~m}$ in length) or exposed bedrock surfaces (e.g., tors). In each case, the Schmidt hammer was held perpendicular to the surface, avoiding rough, irregular or lichen covered areas. To ensure that the sampled surfaces had been exposed to weathering continuously since deglaciation, samples were taken from sites away from cliff faces or valley walls, and in many cases sampled boulders were located on moraine crests (e.g., Fig. 3). At each location (e.g., on each moraine or summit) three surfaces and/or boulders were sampled, and, for each, $30 \mathrm{R}$-values were recorded (from numerous positions on each surface). In order to assess loss in Schmidt hammer condition over time, the same granite boulder was analysed at the beginning and end of sampling. This indicated a 2 point difference in $\mathrm{R}$-values between the beginning (6 May 2016) and end of sampling (23 July 2016). By arranging the R-values chronologically, based on the date/time of collection, a correction was made assuming a linear deterioration in Schmidt hammer performance (following Tomkins et al., 2016). To utilise Tomkins et al. (2016) R-value to numerical age curve for granite, our Schmidt Hammer required calibration against the University of Manchester calibration boulder (see Dortch et al., 2016). This returned an average $\mathrm{R}$-value of $48.70 \pm 1.3$, compared to the calibration value of $48.08 \pm 0.82$ reported by (Tomkins et al., 2016), and values were corrected to account for this difference.

Despite the lack of independent dating control, a number of characteristics likely make the Mournes a suitable location for applying the SHED approach outlined above, First, the mountains are dominated by granite lithology (see Fig. 1B), meaning that the calibration curve in Fig. 2 can be directly applied. Second, the mountain range is comparatively small $(\sim 150$ $\mathrm{km}^{2}$ ) meaning that variations in climate (known to influence rock weathering rates) between sampled surfaces are likely to be minimal. Third, since the calibration curve (Fig. 2) is based 
on dated surfaces from areas of the UK submerged beneath the BIIS during the LGM, and fully deglaciated by the onset of the Holocene, it is only really applicable to surfaces exposed during this period. Fortunately, the Mournes are considered to have experienced a similar glacial history to the sites sampled by Tomkins et al. (2016).

The granite SHED curve of Tomkins et al. (2016) is based on TCND, therefore SHED inherits some of the weaknesses of TCN methods. For example, rock surfaces can be exposed prior to final deposition, which would lead to a softer surface (lower R-value) and inherited TCNs. Conversely, post-depositional rock surfaces that have been exhumed or have spalled part of their surface off would lead to higher R-values and a reduced TCN concentration. Therefore, the calibrated SHED ages need to be analysed with appropriate statistics. Here, we followed the methods of Dortch et al. (2013) and Murari et al. (2014) and used the "ksdensity" kernal in MATLAB 2015a to produce probability density estimates (PDE). The PDEs were then modelled to separate out Gaussians to eliminate positive or negative skew. The highest probability Gaussian is selected with the peak and $1 \sigma$ uncertainties reported, since all ages are younger than the LGM (c.f. Dortch et al., 2013). Ages within $2 \sigma$ that contribute to one of the selected Gaussians were compared using a two-tailed unequal-variance Student's T-Test to determine if events are different.

\section{Glacier reconstruction}

The dimensions of Younger Dryas glaciers in the Mournes were reconstructed from mapped moraines. Based on the results of SHED, all cirques in the Mournes were presumed to have been occupied by glaciers during this period. Three-dimensional reconstructions of glaciers within, and/or emanating from, these cirques were generated using the GIS tool of Pellitero et al. (2016). In each case, a basal shear stress of $100 \mathrm{kPa}$ was applied, using a step length of 10 m (for details see Pellitero et al., 2016).

\section{Equilibrium-line altitude estimates}

A glacier's equilibrium-line altitude (ELA) is defined as the altitude where net annual accumulation and ablation are equal, and is largely controlled by climate (Ohmura et al., 1992). Estimating palaeo ELAs is therefore an established approach for obtaining palaeoclimatic information from glacier reconstructions (see Porter, 2001; Osmaston, 2005). In the present study, ELA was estimated using the GIS tool of Pellitero et al. (2015), applying the AreaAltitude Balance Ratio (AABR) method (considered the most robust method), with an AABR of $1.9 \pm 0.81$ (following Rea, 2009). As noted above, ELA is linked to climate, however in some instances, particularly in the case of small glaciers, ELA is also strongly influenced by non-climatic factors, such as the supply of snow and ice from indirect sources (i.e., from surrounding topography) (Kern and László, 2010). In order to assess the impact of this 'redistributed' snow and ice on the ELAs of reconstructed Younger Dryas glaciers in the Mournes, combined snow and avalanche contributing ratios were calculated (see Ballantyne, $2007 \mathrm{a}, \mathrm{b})$. This involved calculating the ratio of a glacier's potential avalanche and snow contributing area $\left(A_{c}\right)$ to its total surface area $\left(A_{g}\right)$ (see Ballantyne, 2007a,b). A large $\mathrm{Ac} / \mathrm{Ag}$ suggests a greater potential for redistributed snow and ice to make a notable contribution to glacier accumulation. In applying this approach to the Mournes, it was assumed that snowbearing winds during the Younger Dryas were dominantly sourced from the west/SW (210$300^{\circ}$ ), as they are today (Betts, 1997).

\section{Links to palaeoclimate}

In order to estimate the climate necessary to sustain the reconstructed Younger Dryas glaciers in the Mournes, degree-day modelling (DDM) was utilised (see Laumann and Reeh, 1993; Braithwaite et al., 2006). This approach, which has been widely adopted elsewhere (e.g., 
Hughes and Braithwaite, 2008; Barr and Clark, 2011; Bendle and Glasser, 2012), involves using an independent estimate of palaeotemperature to calculate annual melt (i.e., ablation) at the ELAs of reconstructed glaciers, based on as assumed melt rate. In the DDM approach, annual melt $\left(\mathrm{M}_{\mathrm{a}}\right)$ at a glacier's ELA is calculated as the annual sum of daily melt values $\left(\mathrm{M}_{\mathrm{d}}\right)$. Daily melt values are calculated by multiplying positive (i.e., $>0{ }^{\circ} \mathrm{C}$ ) mean daily temperature $\left(\mathrm{T}_{\mathrm{d}}\right)$ by a degree-day melt factor (DDF) (eq. 1).

$\mathrm{M}_{\mathrm{d}}=\mathrm{T}_{\mathrm{d}} \times \mathrm{DDF}($ eq. 1)

In this study a DDF of $4.1 \pm 1.5 \mathrm{~mm}^{\circ} \mathrm{C}^{-1}$ day $^{-1}$ was used (Braithwaite 2008). By assuming that the annual distribution of temperatures is described by a sine curve (Hughes and Braithwaite, 2008), mean daily temperature $\left(T_{d}\right)$ during the Younger Dryas was calculated from eq.2., using independent estimates of mean annual temperature $\left(\mathrm{T}_{\mathrm{a}}\right)$ and annual temperature range $\left(\mathrm{A}_{\mathrm{y}}\right)$ during this period (both from Isarin et al., 1998).

$\mathrm{T}_{\mathrm{d}}=\mathrm{A}_{\mathrm{y}} \sin \left(\frac{2 \pi \mathrm{d}}{\lambda}-\phi\right)+\mathrm{T}_{\mathrm{a}}$ (eq. 2)

where $A_{y}$ is the amplitude of annual temperature variability (1/2 of the annual temperature range), $d$ the ordinal day, $\lambda$ is the period (365 days), $\phi$ is the phase angle of the sine curve (here 1.93 radians based on the general assumption that temperature is maximal in July and minimal in January), and $\mathrm{T}_{\mathrm{a}}$ is mean annual air temperature.

Since net annual accumulation and ablation at the ELA are considered equal, $\mathrm{M}_{\mathrm{a}}$ calculated using this approach is considered an estimate of annual accumulation (considered a proxy for palaeoprecipitation) at the ELA of reconstructed glaciers.

\section{Results}

\section{Geomorphology}

Based on geomorphological mapping, it is apparent that distinct moraine sequences are found within, and adjacent to (within 500-1500 m), cirques in the Mournes (Fig. 1A). These upland moraines are distributed radially around the mountains, suggesting that they were deposited by mountain-centred ice masses, rather than by external ice flowing from the North. This assertion is supported by the lithology of debris within the moraines, which is predominantly comprised of locally-sourced Mourne granite (Wilson, 2004a). As such, these ridges are considered to have been deposited by former mountain- or cirque-style glaciers (Sutton, 1998; Wilson, 2004a). Lowland moraines occupy many of the region's trunk valleys (see Fig. 1A) and are widely presumed to have been deposited during the Killard Point Stadial, when larger glaciers occupied some valleys, and tongues of ice extended through the mountains from the BIIS located to the North (Sutton, 1998).

\section{Chronology}

To establish a chronology of deglaciation in the Mournes, a total of 53 separate locations (on mountain summits, cols, valleys, and cirques) were sampled for Schmidt hammer dating (see Fig. 1A). At each location, 30 R-values were recorded from 3 different surfaces (boulders or bedrock) - with measurements taken from numerous positions on each surface. Resulting SHED age estimates range from $6.5 \pm 0.8 \mathrm{ka}$ to $20.1 \pm 1.0 \mathrm{ka}$ (see supplementary information). Selected Gaussians from PDE models show a distinction between summit (15.6 $\pm 1.9 \mathrm{ka})$, col $(14.2 \pm 1.7 \mathrm{ka})$, valley $(10.5 \pm 1.4 \mathrm{ka})$ and cirque $(8.8 \pm 0.8 \mathrm{ka})$ locations (Fig. 4$)$. The Gaussian models show a considerable amount of post-glacial exhumation or surface spallation affecting 
summit and col age distributions (Fig. 4A-B). In contrast, cirque and valley age distributions are skewed by exposure prior to deposition leading to softer surfaces (Fig. 4C-D). Prior exposure is a common issue with TCND in the UK due to the lower erosivity of Younger Dryas ice. Cirque SHED age distribution is also considerably affected by exhumation or spalling of surfaces, which indicates considerable post-depositional reworking. P-values resulting from TTests on ages for each landform type within $2 \sigma$ of the selected Gaussians are all $<0.01$. This indicates that, while there is some overlap of uncertainties, the events are statistically distinguishable and separate (See table 1). The data indicate that summits deglaciated following the LGM, closely followed by cols. Valleys last deglaciated during the late glacial (during phases of ice sheet readvance) and cirques last deglaciated following the Younger Dryas. The age estimates show some relationship with altitude $\left(\mathrm{R}^{2}=0.27\right.$, P-value $<0.01$; Fig. 5). However, low altitude valley samples typically return older age estimates than higher altitude cirques (Fig. 5), thus the relationship likely reflects the region's glacial history, rather than an altitudinal control on the rate of post-glacial weathering (see Tomkins et al., 2016).

\section{Younger Dryas glaciers and their ELAs}

On the basis of the geomorphological mapping and SHED chronology, 24 Younger Dryas glaciers were reconstructed in the Mournes (see Fig. 6). In places where multiple moraines potentially mark Younger Dryas ice margins, both minimum and maximum glacier reconstructions were generated (see Fig. 6). In total, the reconstructions indicate that during the Younger Dryas, the mountains were occupied by glaciers with a total surface area of 3.42$5.24 \mathrm{~km}^{2}$ (see Table 2). These glaciers have ELAs ranging from $356 \pm 33 \mathrm{~m}$ (a.s.1.) to $570 \pm 9$ $\mathrm{m}$ (a.s.1.), with a mean ELA of $475 \pm 36 \mathrm{~m}$ (a.s.1.) (Table 2). Values for individual glaciers typically rise from west to east (Fig. 7A). This trend might reflect a precipitation gradient during the Younger Dryas, however when the impact of redistributed snow and ice is considered (Mitchell, 1996; Carrivick and Brewer, 2004), results indicate that ELA and snowblow and avalanche ratios $\left(\mathrm{A}_{\mathrm{c}} / \mathrm{A}_{\mathrm{g}}\right)$ are related (Fig. 7B-C), and that glaciers in the western Mournes (labelled 1 and 2 in Figs. 7A \& B) have comparatively large snowblow and avalanche ratios. This likely reflects their position on the lee (eastern) side of an extensive $\left(\sim 6 \mathrm{~km}^{2}\right)$ upland plateau (Wilson, 2004a) (see Fig. 1A). This applies when both the minimum (Fig. 7B) and maximum (Fig. 7C) glacier reconstructions are considered. It is therefore possible that the plentiful supply of redistributed snow and ice explains the low ELAs of these glaciers, and that the West-East ELA gradient (Fig. 7A) is not climatically driven. Thus the reported mean ELA of glaciers in the Mournes during the Younger Dryas (i.e., $475 \pm 36 \mathrm{~m}$ ) (Table 2), is likely partly controlled by the availability of redistributed snow and ice (and cannot be directly linked to climate). In order to estimate a 'climatic' ELA, the regression lines in Fig. 7B-C can be extrapolated to simulate conditions for a hypothetical glacier receiving no accumulation from redistributed snow or ice (i.e., Ac/Ag = 0) (see Bendle and Glasser, 2012). Applying this technique in the Mournes yields a mean 'climatic' ELA of $529 \pm 4$ m (a.s.1.).

\section{Degree-day model output}

The DDM approach is used to predict annual accumulation in the Mournes during the Younger Dryas based on reconstructed glaciers and independent estimates of mean annual temperature and annual temperature range during this period. To simulate the coldest part of the Younger Dryas, a mean annual sea level air temperature of $-8^{\circ} \mathrm{C}$, and an annual temperature range of $34^{\circ} \mathrm{C}$ are assumed (Isarin et al., 1998). With a DDF of $4.1 \pm 1.5 \mathrm{~mm}^{\circ} \mathrm{C}^{-1}$ day $^{-1}$ (Braithwaite 2008), and an environmental lapse rate of $0.006-0.007^{\circ} \mathrm{C} \mathrm{m}^{-1}$ (Bendle and Glasser, 2012), this approach predicts annual accumulation of $844-2132 \mathrm{~mm} \mathrm{a}^{-1}$ at the mean 'climatic' ELA of Younger Dryas glaciers in the Mournes (Table 3). 


\section{Discussion}

\section{A deglacial chronology for the Mournes}

Results from SHED in the Mournes (see supplementary information, and Fig. 4) are broadly consistent with the existing view of post-LGM glaciation in the region. Specifically, results indicate that summits were last deglaciated during ice sheet retreat from the LGM, and that the higher cols were then exposed (Fig. 4). Valleys were last deglaciated during the late glacial (likely during a phase of ice sheet readvance), and cirques were last glaciated during the Younger Dryas. Despite the evidence to support this pattern, it is notable that the age estimates derived from the SHED approach are typically younger (more recent) than suggested by 'established' chronologies (Fig. 4). However, there are few chronologies available for comparison in Norther Ireland. Alternatively, the younger ages may indicate a limitation of the SHED approach applied here. Specifically, the local climate, or local granite that is slightly different to the granites in the calibration dataset, might mean that the Schmidt hammer calibration curve of Tomkins et al. (2016) is not directly applicable to the Mournes - something which might be addressed by establishing an independent cosmogenic chronology, from which a local Schmidt hammer calibration curve (equivalent to Fig. 2) could be constructed. Despite this, the SHED approach differentiates between different phases of glaciation in the Mournes (Fig. 4), and is considered a viable method for constraining the extent of the region's glaciers during the Younger Dryas.

\section{Younger Dryas climate in the Mournes}

Meteorological data from Annalong (130 m a.s.1., $\left.54.11^{\circ} \mathrm{N}, 5.90^{\circ} \mathrm{W}\right)$ (labelled in Fig. 1A) reveals modern precipitation (AD 1931-1994) of $1227 \mathrm{~mm} \mathrm{a}^{-1}$ (Peterson and Vose, 1997). Adjusted to an altitude of $529 \pm 4 \mathrm{~m}$ (a.s.1.), and assuming a rate of precipitation increase with altitude of $3.0 \mathrm{~mm} \mathrm{~m}^{-1}$ (Brunsdon et al., 2001), yields a modern precipitation estimate of 2424 $\pm 12 \mathrm{~mm} \mathrm{a}^{-1}$ at the 'climatic' ELA of Younger Dryas glaciers in the Mournes. By contrast, model data from the present study indicate that during the Younger Dryas, accumulation at this altitude was $844-2132 \mathrm{~mm} \mathrm{a}^{-1}$. This suggests a reduction in mean annual precipitation, relative to present. In fact, the temperature data used in the DDM (see Isarin et al., 1998), with notably low winter temperatures and a greater annual temperature range, suggest that the Mournes likely experienced comparatively continental conditions during the Younger Dryas. Under such conditions, model outputs based on a DDF of 2.6 (the lowest value used in the present study) might be a better representation of 'true' Younger Dryas conditions (since higher DDFs are unrepresentative of glaciers occupying continental climates - see Braithwaite et al., 2006; Hughes, 2009). When the model is run with a DDF of 2.6, results indicate mean accumulation of 846-990 $\mathrm{mm} \mathrm{a}^{-1}$ (Table 3), suggesting notable aridity during the Younger Dryas, relative to present. Unfortunately, though independent palaeoenvironmental proxies indicate cooling, landscape instability and the expansion of arctic shrub tundra in Ireland during the Younger Dryas (Watson et al., 2010; Walker et al., 2012), there is little information about precipitation during this period against which to validate these inferences. Despite this, the precipitation values reported here are comparable to those reconstructed for the Younger Dryas in parts of central and western Scotland (see Table 5 in Boston et al., 2015), but generally lower than for parts of NW Wales (see Table 2 in Bende and Glasser, 2012).

\section{Regional comparison}

Modelling results from the present study suggest that Younger Dryas climate in the Mournes was continental, with particularly cold winters and reduced precipitation relative to present. Similar conditions have been proposed for other regions bordering the Irish Sea. For example, the Isle of Arran (Ballantyne, 2007a,b), Southern uplands (Cornish, 1981; Gordon, 1999), English Lake District (Sissons, 1980; Walker, 2004), and NW Wales (Bendle and Glasser, 
2012), are considered to have been notably drier than present during the Younger Dryas. Bendle and Glasser (2012) note that evidence for drier conditions is generally consistent with proxy archives (e.g. Isarin and Renssen, 1999) and ice core evidence (Alley, 2000) which suggest reduced annual snowfall across NW Europe during the Younger Dryas. The consensus view is that this aridity occurred as a result of low winter temperatures causing the formation of extensive sea ice (down to $\sim 50-52^{\circ} \mathrm{N}$ ) in the North Atlantic (Renssen and Isarin, 1998; Renssen and Vandenberghe, 2003; Golledge et al., 2010). Thus, conditions during this period may have been notably seasonal, with dry, arid winters (when sea ice was at its most extensive) and comparatively mild summers (Golledge, 2010; Bendle and Glasser, 2012). Under such conditions, moisture availability from the North Atlantic is considered to have been an important control on glaciation in NW Europe, with dominant westerly and southwesterly winds generating strong West-East precipitation (and associate ELA) gradients (Ballantyne, 1989; Sissons, 1979, 1980; Hughes, 2009; Golledge, 2010). For example, at Achill Island on the west coast of Ireland ( $\sim 260 \mathrm{~km}$ west of the Mournes) moisture from the North Atlantic is considered to have sustained Younger Dryas glaciers with ELAs close to modern sea level (Bowen et al., 2002; Ballantyne et al., 2008), whereas in central and eastern Scotland ELAs were $>700 \mathrm{~m}$ (a.s.1.) (Boston et al., 2015). Under such continental conditions, glaciers in the Mournes are likely to have been comparatively moisture-starved, and partly sustained because of a shortened ablation season, and the plentiful supply of redistributed snow and ice (Sutton, 1998). Golledge (2010) suggests that in western Scotland, extreme continental conditions during the most severe period of the Younger Dryas (with climate $6-8^{\circ} \mathrm{C}$ cooler than present during the summer months, but as much as $30^{\circ} \mathrm{C}$ colder during the winter) were unconducive to glacier growth, and that perhaps glaciers were at their most extensive during the early stages of the Younger Dryas, when temperature depression and sea-ice induced aridity were less severe (Walker et al., 2003; Walker, 2004; Bendle and Glasser, 2012). This may be true for the Mournes, and might explain why sequences of moraines are found within inferred maximum Younger Dryas glacier limits (Fig. 1A) - i.e., perhaps these 'inner' moraines reflect less extensive advances and/or periods of stabilisation during overall retreat from an early Younger Dryas ice extent maximum. Similar evidence, to suggest the development of comparatively extensive glaciers during the early Younger Dryas, has been found in other regions bordering the Irish Sea (see Bendle and Glasser, 2012).

Despite the evidence for increased aridity and continentality in NW Europe during the Younger Dryas, some regions appear to indicate precipitation totals comparable to, or even greater than, present. For example, in NW Scotland, there is some evidence of increased precipitation (by up to 26\%) during the Younger Dryas (Ballantyne, 1989; Benn and Lukas, 2006; Lukas and Bradwell, 2010). However, in NW Scotland elevated precipitation is partly attributable to increased storminess, combined with the local presence of the Western Highlands ice field (see Golledge, 2008), which forced westerly and southwesterly air masses to rise and cool, meaning that adjacent areas (to the west) received heavy snowfall (Sissons, 1979, 1980; Ballantyne, 2007a,b). Such conditions are unlikely to have prevailed in the Mournes, and evidence from the present study appears to support the idea that Younger Dryas climate in Northern Ireland was colder, drier, and more continental than present. In fact, it is notable that insolation at these latitudes, and atmospheric $\mathrm{CO}_{2}$ concentrations, were relatively high during the Younger Dryas (relative to earlier cold periods) (Imbrie et al., 1984; Liu et al., 2013), but freshwater inputs, ice bergs and sea-ice acted to cool North Atlantic climate by disrupting oceanic and atmospheric circulation (Isarin et al., 1998; Bakke et al., 2009; Golledge, 2010).

\section{Conclusions}


In this study, the extent of Younger Dryas glaciers in Mourne Mountains, Northern Ireland, has been reconstructed, and used to infer regional palaeoclimate. The main study findings are summarised as follows:

1. Geomorphological mapping reveals upland moraine sequences, suggesting the former presence of cirque and valley glaciers.

2. Results of SHED appear to chronologically constrain these moraines to the Younger Dryas, and are broadly consistent with the 'established' view of post-LGM deglaciation from the Mournes - i.e., with summits and some cols last deglaciated following the LGM, valleys last deglaciated during the late glacial (during phases of ice sheet readvance) and cirques last deglaciated following the Younger Dryas.

3. On the assumption that the region's cirques were last occupied during the Younger Dryas, 24 glaciers, covering $3.42-5.24 \mathrm{~km}^{2}$, are reconstructed for this period. These glaciers have ELAs ranging from $356 \pm 33 \mathrm{~m}$ (a.s.1.) to $570 \pm 9 \mathrm{~m}$ (a.s.1.), with a mean of $475 \pm 36 \mathrm{~m}$ (a.s.1.). These ELA estimates rise from west to east, but this is considered to reflect the supply of redistributed snow and ice to glaciers occupying the western Mournes, rather than indicating a clear climatic gradient.

4. When the role of redistributed snow and ice is accounted for, a Younger Dryas 'climatic' ELA of $529 \pm 4 \mathrm{~m}$ (a.s.1.) is calculated for the mountains.

5. Assuming mean annual sea level air temperature of $-8^{\circ} \mathrm{C}$ and an annual temperature range of $34^{\circ} \mathrm{C}$ (Isarin et al., 1998), degree-day modelling suggests that during the Younger Dryas, annual accumulation at the 'climatic' ELA of glaciers in the Mournes was 844-2132 $\mathrm{mm} \mathrm{a}^{-1}$. However, given evidence for increased continentality in the region, annual accumulation was likely in the 846-990 $\mathrm{mm} \mathrm{a}^{-1}$ range, suggesting notably increased aridity relative to present. As in other parts of NW Europe, this reduction in precipitation, alongside notable cooling (with cooling of $7.0^{\circ} \mathrm{C}$ in summer, and $28.2^{\circ} \mathrm{C}$ in winter) is thought to reflect extensive North Atlantic sea ice (suppressing evaporation) during the Younger Dryas.

\section{Acknowledgements}

We would like to thank Danny McCarroll for his corrections, comments, and suggestions which helped improve this manuscript.

\section{References}

Alley RB. 2000. The Younger Dryas cold interval as viewed from central Greenland. Quaternary Science Reviews 19: 213-226.

Anderson E, Harrison S, Passmore DG, Mighall TM. 1998. Geomorphic evidence of Younger Dryas glaciation in the Macgillycuddy's Reeks, south west Ireland. Quaternary Proceedings 6: 75-90.

Aydin A, Basu A. 2005. The Schmidt hammer in rock material characterization. Engineering Geology 81: 1-14.

Bakke J, Lie Ø, Heegaard E, Dokken T, Haug GH, Birks HH, Dulski P, Nilsen T. 2009. Rapid oceanic and atmospheric changes during the Younger Dryas cold period. Nature Geoscience 2(3): 202-205. 
Ballantyne CK. 1989. The Loch Lomond Advance on the Isle of Skye, Scotland: glacier reconstruction and palaeoclimatic implications. Journal of Quaternary Science 4: 95-108.

Ballantyne CK. 2007a. Loch Lomond Stadial glaciers in North Harris, Outer Hebrides, NorthWest Scotland: glacier reconstruction and palaeoclimatic implications. Quaternary Science Reviews 26: 3134-3149.

Ballantyne CK. 2007b. The Loch Lomond Readvance on north Arran, Scotland: glacier reconstruction and palaeoclimatic implications. Journal of Quaternary Science 22(4): 343359.

Ballantyne CK, Stone JO, McCarroll D. 2008. Dimensions and chronology of the last ice sheet in Western Ireland. Quaternary Science Reviews 27(3): 185-200.

Barr ID, Clark CD. 2011. Glaciers and climate in Pacific Far NE Russia during the Last Glacial Maximum. Journal of Quaternary Science 26(2): 227-237.

Bazley RAB. 2004. Quaternary. In The Geology of Northern Ireland, Our Natural Foundation, Mitchell W (ed.). The Geological Survey of Northern Ireland: Belfast; 211-226.

Bendle JM, Glasser NF. 2012. Palaeoclimatic reconstruction from lateglacial (younger dryas chronozone) cirque glaciers in snowdonia, north wales. Proceedings of the Geologists' Association 123(1): 130-145.

Benn DI, Lukas S. 2006. Younger Dryas glacial landsystems in North West Scotland: an assessment of modern analogues and palaeoclimatic implications. Quaternary Science Reviews 25: 2390-2408.

Betts, N., 1997. Climate. In Soil and Environment: Northern Ireland, Cruickshank JG (ed.). Agricultural and Environmenral Science Division: Queen's University Belfast.

Boston CM, Lukas S, Carr SJ. 2015. A Younger Dryas plateau icefield in the Monadhliath, Scotland, and implications for regional palaeoclimate. Quaternary Science Reviews 108: 139162.

Bowen DQ, Phillips FM, McCabe AM, Knutz PC, Sykes GA. 2002. New data for the last glacial maximum in Great Britain and Ireland. Quaternary Science Reviews 21: 89-101.

Braithwaite RJ. 2008. Temperature and precipitation climate at the equilibrium line altitude of glaciers expressed by the degree-day factor for melting snow. Journal of Glaciology 54: 437444.

Braithwaite RJ, Raper SCB, Chutko K. 2006. Accumulation at the equilibrium line altitude of glaciers inferred from a degree-day model and tested against field observations. Annals of Glaciology 43: 329-334.

Brown VH, Evans, DJ, Vieli A, Evans IS. 2013. The Younger Dryas in the English Lake District: reconciling geomorphological evidence with numerical model outputs. Boreas 42(4): $1022-1042$. 
Brunsdon C, McClatchey J, Unwin DJ. 2001. Spatial variations in the average rainfall-altitude relationship in Great Britain: an approach using geographically weighted regression. International journal of climatology 21(4): 455-466.

Carrivick JL, Brewer TR. 2004. Improving local estimations and regional trends of glacier equilibrium line altitudes. Geografiska Annaler 86: 67-79.

Charlesworth JK. 1938. Some observations on the glaciation of north-east Ireland. Proceedings of the Royal Irish Academy. Section B: Biological, Geological, and Chemical Science 45: 255295.

Clark CD, Hughes AL, Greenwood SL, Jordan C, Sejrup HP. 2012. Pattern and timing of retreat of the last British-Irish Ice Sheet. Quaternary Science Reviews 44: 112-146.

Colhoun EA, Synge FM. 1980. The cirque moraines at Lough Nahanagan, County Wicklow, Ireland. Proceedings of the Royal Irish Academy. Section B: Biological, Geological, and Chemical Science 80B: 25-45.

Cooper MR, Johnston TP. 2004. Palaeogene Intrusive Igneous Rocks. In The Geology of Northern Ireland, Our Natural Foundation, Mitchell W (ed.). The Geological Survey of Northern Ireland: Belfast; 179-198.

Cornish R. 1981. Glaciers of the Loch Lomond Stadial in the western Southern Uplands of Scotland. Proceedings of the Geologists Association 92: 105-114.

Dortch JM, Hughes PD, Tomkins MD. 2016. Schmidt Hammer exposure dating (SHED): Calibration boulder of Tomkins et al. (2016). Quaternary Geochronology 35: 67-68.

Dortch JM, Owen LA, Caffee MW. 2013. Timing and climatic drivers for glaciation across semi-arid western Himalayan-Tibetan orogen. Quaternary Science Reviews 78: 188-208.

Dwerryhouse AR. 1923. The glaciation of north-eastern Ireland. Quarterly Journal of the Geological Society 79(1-4): 352-422.

Fairbanks RG. 1990. The age and origin of the "Younger Dryas climate event" in Greenland ice cores. Paleoceanography 5(6): 937-948.

Gellatly AF. 1985. Introduction to the glacial history of the Mourne Mountains. In 1st International conference on geomorphology, Northern Ireland Fieldtrip, Whalley WB, Smith BJ, Orford JD, Carter RWG (eds). Queen's University of Belfast Department of Geography.

Golledge NR. 2008. Glacial Geology and Glaciology of the Younger Dryas Ice Cap in Scotland (Unpublished PhD thesis). University of Edinburgh.

Golledge NR. 2010. Glaciation of Scotland during the Younger Dryas: a review. Journal of Quaternary Science 25: 550-566.

Golledge NR, Hubbard AL, Bradwell T. 2010. Influence of seasonality on glacier mass balance, and implications for palaeoclimate reconstructions. Climate Dynamics 35: 757-770. 
Gordon JE. 1999. Loch Skene: Loch Lomond Readvance moraine system. In The Quaternary of Dumfries and Galloway: Field Guide, Tipping RM (ed.). Quaternary Research

Association: London; 164-167.

Goudie AS. 2006. The Schmidt Hammer in geomorphological research. Progress in Physical Geography 30: 703-718.

GSI, Geological Survey of Ireland, 1:500,000 Bedrock Geology of Ireland. 2016. http://www.dccae.gov.ie/natural-resources/en-ie/Geological-Survey-of-Ireland/Pages/DataDownloads.aspx [2 August 2016].

Harrison S, Glasser N, Anderson E, Ivy-Ochs S, Kubik PW. 2010. Late Pleistocene mountain glacier response to North Atlantic climate change in southwest Ireland. Quaternary Science Reviews 29(27): 3948-3955.

Hughes PD. 2009. Loch Lomond Stadial (Younger Dryas) glaciers and climate in Wales. Geological Journal 44: 375-391.

Hughes PD, Braithwaite RJ. 2008. Application of a degree-day model to reconstruct Pleistocene glacial climates. Quaternary Research 69: 110-116.

Imbrie J, Hays JD, Martinson DG, McIntyre A, Mix AC, Morley JJ, Pisias NG, Prell WL, Shackleton NJ. 1984. The orbital theory of Pleistocene climate: Support from a revised chronology of the marine $\delta^{18} \mathrm{O}$ record. In Milankovitch and Climate, Vol. Series C, 126, Berger A et al. (ed.). NATO ASI, Springer: Berlin; 269-305.

Isarin RFB, Renssen H. 1999. Reconstructing and modelling late Weichselian climates: the Younger Dryas in Europe as a case study. Earth-Science Reviews 48: 1-38.

Isarin RFB, Renssen H, Vandenberghe J. 1998. The impact of the North Atlantic Ocean on the Younger Dryas climate in northwestern and central Europe. Journal of Quaternary Science 13(5): 447-453.

Kern Z, László P. 2010. Size specific steady-state accumulation-area ratio: an improvement for equilibrium-line estimation of small palaeoglaciers. Quaternary Science Reviews 29: 27812787.

Laumann T, Reeh N. 1993. Sensitivity to climate change of the mass balance of glaciers in southern Norway. Journal of Glaciology 39: 656-665.

Liu Z, Carlson AE, He F, Brady EC, Otto-Bliesner BL, Briegleb BP, Wehrenberg M, Clark PU, Wu S, Cheng J, Zhang J. 2012. Younger Dryas cooling and the Greenland climate response to $\mathrm{CO}_{2}$. Proceedings of the National Academy of Sciences 109(28): 11101-11104.

Lowe JJ, Rasmussen SO, Björck S, Hoek WZ, Steffensen JP, Walker MJC, Yu ZC, the INTIMATE group. 2008. Synchronisation of palaeoenvironmental events in the North Atlantic region during the Last Termination: a revised protocol recommended by the INTIMATE group. Quaternary Science Reviews 27: 6-17. 
Lukas S. 2006. Morphostratigraphic principles in glacier reconstruction - a perspective from the British Younger Dryas. Progress in Physical Geography 30: 719-736.

Lukas S, Bradwell T. 2010. Reconstruction of a Lateglacial (Younger Dryas) mountain ice field in Sutherland, northwestern Scotland, and its palaeoclimatic implications. Journal of Quaternary Science 25: 567-580.

Matthews JA, Shakesby R. 1984. The status of the "Little Ice Age"in southern Norway: relative-age dating of Neoglacial moraines with Schmidt hammer and lichenometry. Boreas 13: 333-346.

Matthews JA, Owen G. 2010. Schmidt hammer exposure-age dating: developing linear agecalibration curves using Holocene bedrock surfaces from the Jotunheimen-Jostedalsbreen regions of southern Norway. Boreas 39: 105-115.

McCabe AM, Clark PU. 1998. Ice-sheet variability around the North Atlantic Ocean during the last deglaciation. Nature 392: 373-377.

McCabe AM, Clark PU, Clark J, Dunlop P. 2007. Radiocarbon constraints on readvances of the British-Irish Ice Sheet in the northern Irish Sea Basin during the last deglaciation. Quaternary Science Reviews 26(9): 1204-1211.

McCabe M, Dunlop P. 2006. The Last Glacial Termination in Northern Ireland. Geological Survey of Northern Ireland. Geological Survey of Northern Ireland: Belfast.

McCabe AM, Williams GD. 2012. Timing of the East Antrim Coastal Readvance: phase relationships between lowland Irish and upland Scottish ice sheets during the Last Glacial Termination. Quaternary Science Reviews 58: 18-29.

Mitchell, WA. 1996. The significance of snowblow in the generation of Loch Lomond Stadial (Younger Dryas) glaciers in the western Pennines, northern England. Journal of Quaternary Science 11: 233-248.

Murari MK, Owen LA, Dortch JM, Caffee MW, Dietsch C, Fuchs M, Haneberg WC, Sharma MC, Townsend-Small A. 2014. Timing and climatic drivers for glaciation across monsooninfluenced regions of the Himalayan-Tibetan orogen. Quaternary Science Reviews 88: 159182.

Ohmura A, Kasser P, Funk M. 1992. Climate at the equilibrium line of glaciers. Journal of Glaciology 38(130): 397-411.

Osmaston H. 2005. Estimates of glacier equilibrium line altitudes by the Area $\times$ Altitude, the Area $\times$ Altitude Balance Ratio and the Area $\times$ Altitude Balance Index methods and their validation. Quaternary International 138-139: 22-31

Pellitero R, Rea BR, Spagnolo M, Bakke J, Hughes P, Ivy-Ochs S, Lukas S, Ribolini A. 2015. A GIS tool for automatic calculation of glacier equilibrium-line altitudes. Computers \& Geosciences 82: 55-62. 
Pellitero R, Rea BR, Spagnolo M, Bakke J, Ivy-Ochs S, Frew CR, Hughes P, Ribolini A, Lukas $\mathrm{S}$, Renssen H. 2016. Glare, a GIS tool to reconstruct the 3D surface of palaeoglaciers. Computers \& Geosciences 94: 77-85.

Peterson TC, Vose RS. 1997. An overview of the Global Historical Climatology Network temperature database. Bulletin of the American Meteorological Society 78(12): 2837-2849.

Porter SC. 2001. Snowline depression in the tropics during the Last Glaciation. Quaternary Science Reviews 20: 1067-1091.

Rea BR, 2009. Defining modern day Area-Altitude Balance Ratios (AABRs) and their use in glacier-climate reconstructions. Quaternary Science Reviews 28: 237-248.

Rea BR, McCarron S. 2008. The Younger Dryas in the North of Ireland. In North of Ireland: Field Guide, Whitehouse NJ, Roe HM, McCarron S, Knight J (eds). Quaternary Research Association: London.

Renssen H, Isarin RFB. 1998. Surface temperature in NW Europe during the Younger Dryas: AGCM simulation compared with temperature reconstructions. Climate Dynamics 14: 33-44.

Renssen H, Vandenberghe J. 2003. Investigation of the relationship between permafrost distribution in NW Europe and extensive winter sea-ice cover in the North Atlantic Ocean during the cold phases of the Last Glaciation. Quaternary Science Reviews 22: 209-223.

Renssen H, Mairesse A, Goosse H, Mathiot P, Heiri O, Roche DM, Nisancioglu KH, Valdes PJ. 2015. Multiple causes of the Younger Dryas cold period. Nature Geoscience 8: 946-950.

Sissons JB, 1979. Palaeoclimatic inferences from former glaciers in Scotland and the Lake District. Nature 278: 518-521.

Sissons JB. 1980. The Loch Lomond Advance in the Lake District, northern England. Transactions of the Royal Society of Edinburgh: Earth Sciences 71: 13-27.

Stephens N, Creighton JR, Hannon MA. 1975. The Late-Pleistocene period in north-eastern Ireland: an assessment 1975. Irish Geography 8(1): 1-23.

Sutton B. 1998. Glacial Landforms and Sedimentology, and Late Pleistocene Evolution of the Mourne Mountains, Northern Ireland. Unpublished PhD thesis, University of Ulster.

Tomkins MD, Dortch JM, Hughes PD. 2016. Schmidt Hammer exposure dating (SHED): Establishment and implications for the retreat of the last British Ice Sheet. Quaternary Geochronology 33: 46-60.

Walker MJC. 2004. A Lateglacial pollen record from Hallsenna Moor, near Seascale, Cumbria, NW England, with evidence for arid conditions during the Loch Lomond (Younger Dryas) Stadial and early Holocene. Proceedings of the Yorkshire Geological and Polytechnic Society 55(1): 33-42. 
Walker MJC, Coope GR, Sheldrick C, Turney CSM, Lowe JJ, Blockley SPE, Harkness DD. 2003. Devensian Lateglacial environmental changes in Britain: a multi-proxy environmental record from Llanilid, South Wales, UK. Quaternary Science Reviews 22: 475-520.

Walker MJC, Lowe J, Blockley SP, Bryant C, Coombes P, Davies S, Hardiman M, Turney CS, Watson J. 2012. Lateglacial and early Holocene palaeoenvironmental 'events' in Sluggan Bog, Northern Ireland: comparisons with the Greenland NGRIP GICC05 event stratigraphy. Quaternary Science Reviews 36: 124-138.

Watson JE, Brooks SJ, Whitehouse NJ, Reimer PJ, Birks HJB, Turney C. 2010. Chironomidinferred late-glacial summer air temperatures from Lough Nadourcan, Co. Donegal, Ireland. Journal of Quaternary Science 25(8): 1200-1210.

Wilson KR. 2004a. The last glaciation in the western Mourne Mountains, Northern Ireland. The Scottish Geographical Magazine 120(3): 199-210.

Wilson P. 2004b. Evidence for and reconstruction of a Nahanagan Stade glacier at Croloughan Lough, Derryveagh mountains, Co. Donegal. Irish Journal of Earth Sciences 22: 45-54.

Winkler S. 2009. First attempt to combine terrestrial cosmogenic nuclide (10Be) and Schmidt hammer relative-age dating: Strauchon Glacier, Southern Alps, New Zealand. Open Geosciences 1(3): 274-290. 

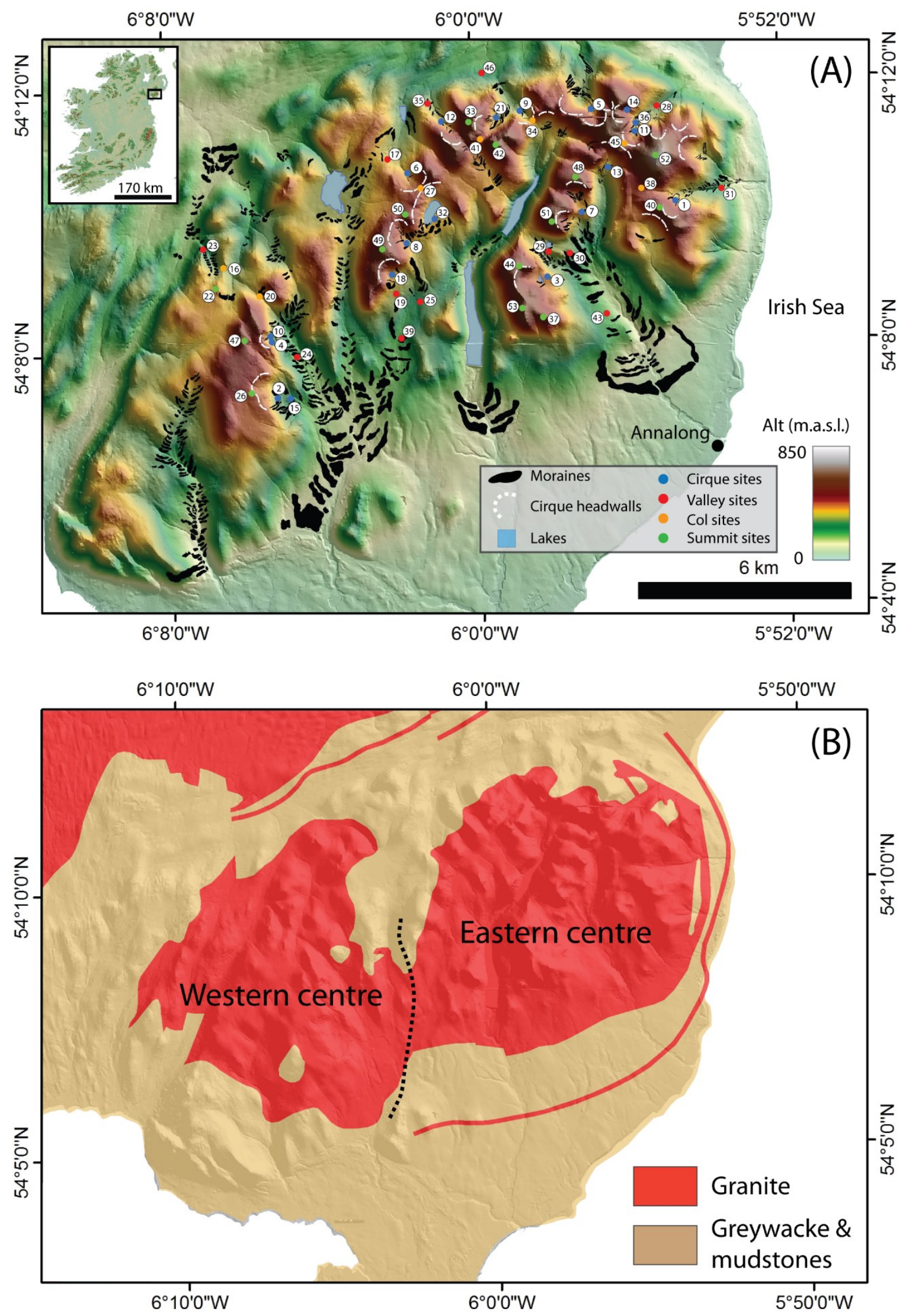

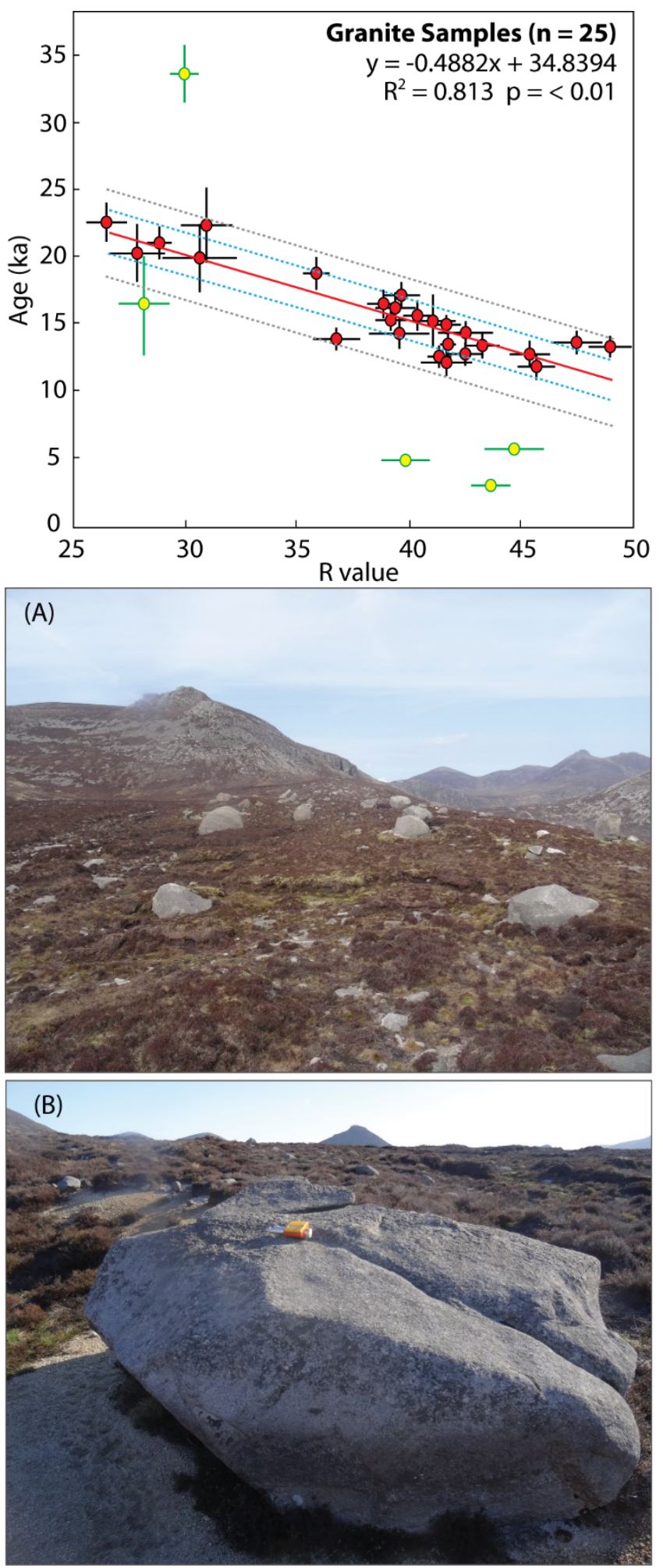


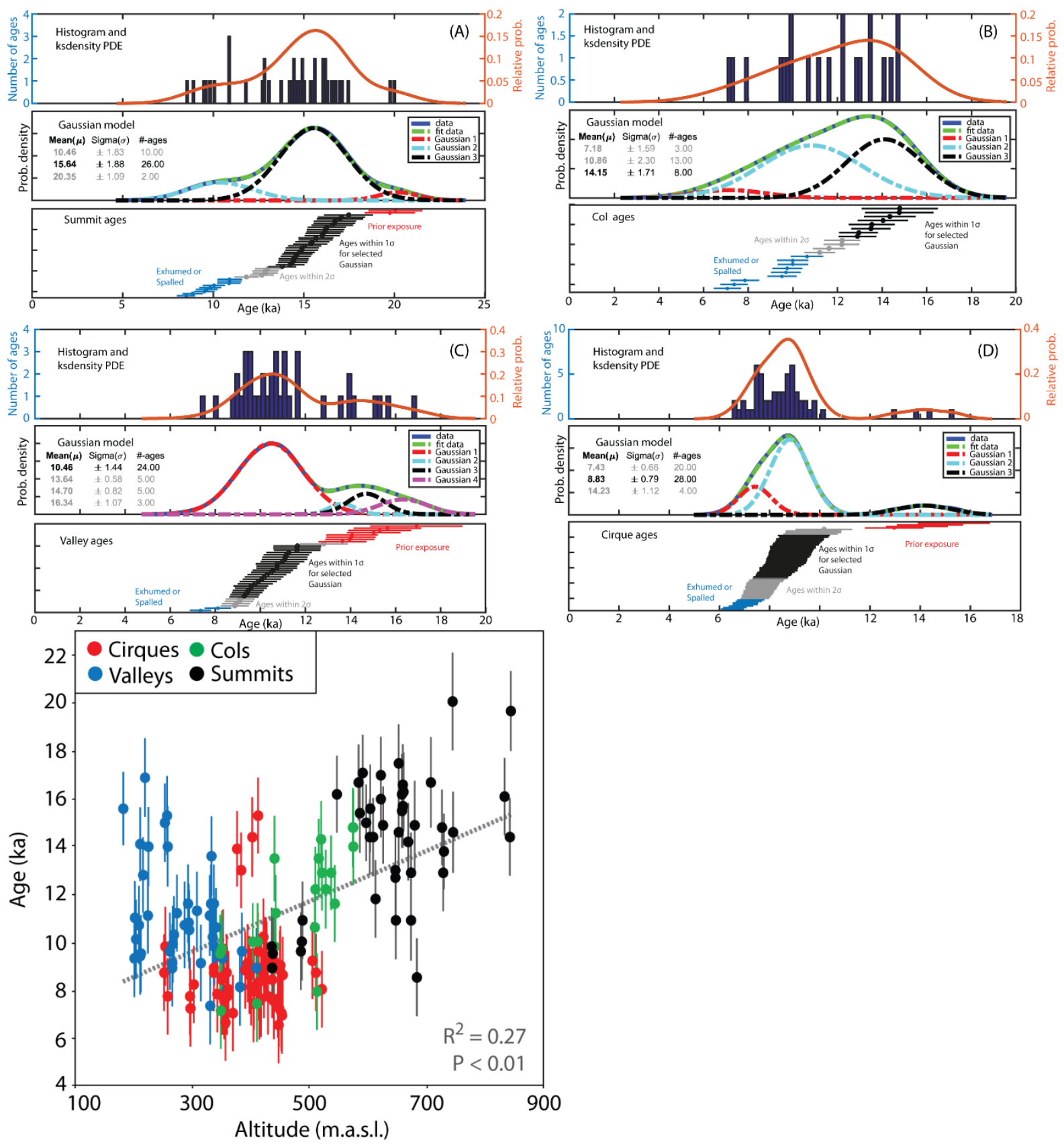



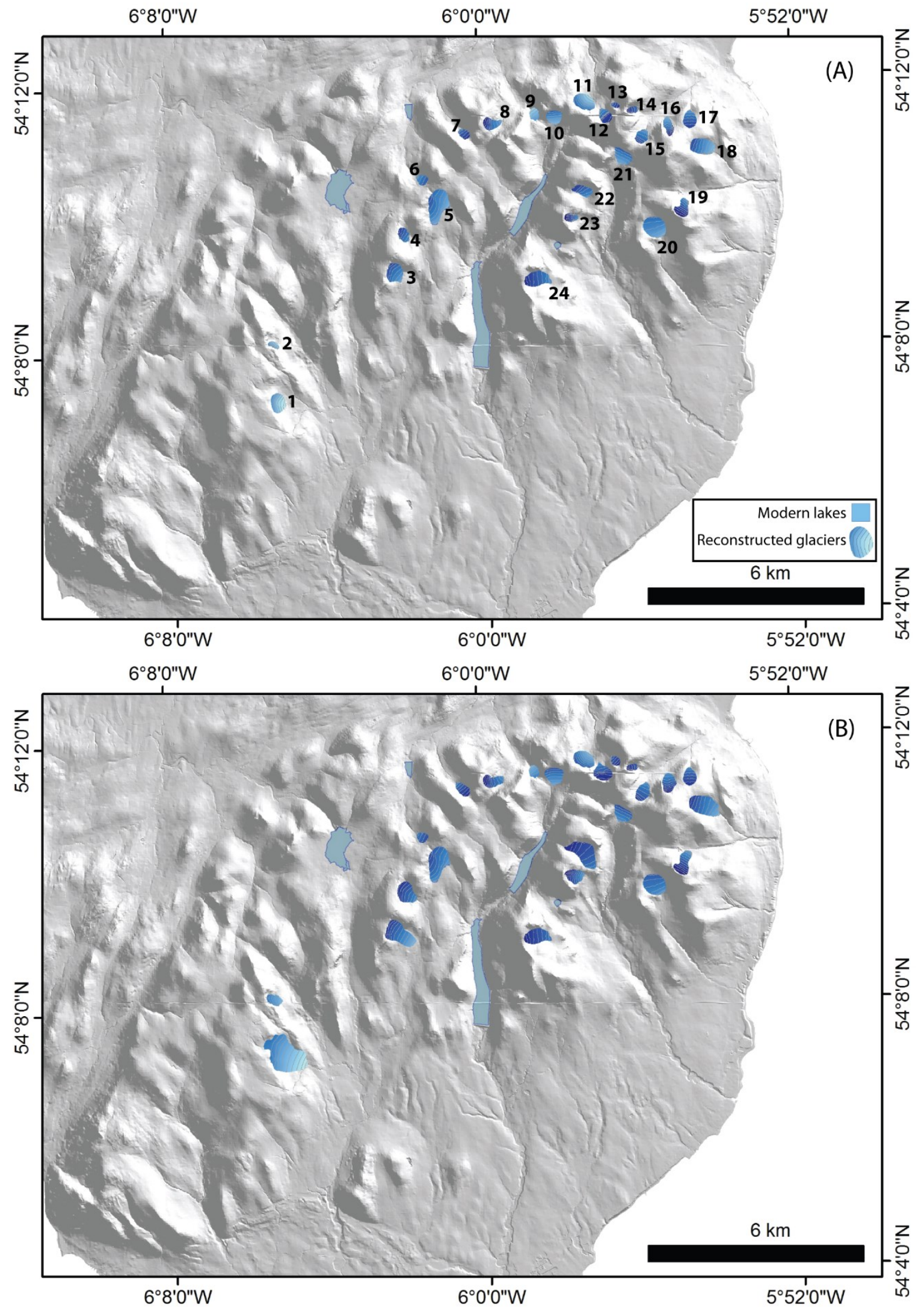


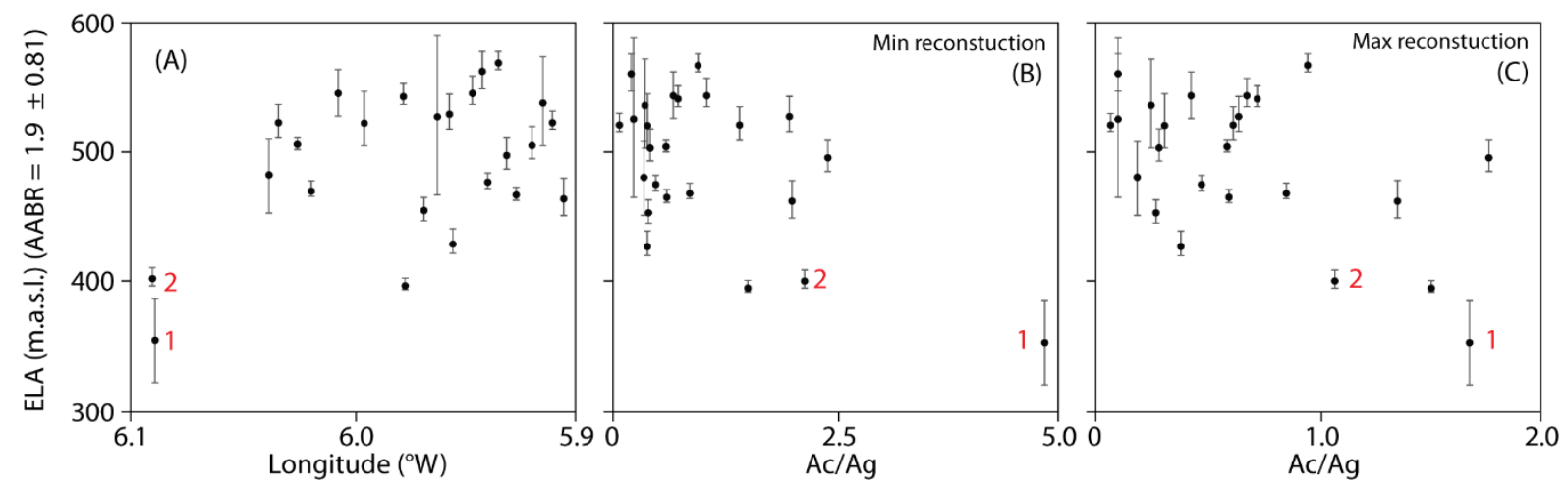

Table 1. The peak age, $1 \sigma$ uncertainties and P-values from T-Test between landform types at $2 \sigma$. P-values represent the relationship between the landform type they are listed across from and the next youngest in the table.

\begin{tabular}{lcc} 
Landform & $\begin{array}{l}\text { Selected } \\
\text { Gaussian age } \\
\text { (Ka) }\end{array}$ & $\begin{array}{l}\text { P-values between } \\
\text { 20 Gaussian ages }\end{array}$ \\
\hline Summit & $15.6 \pm 1.9$ & «0.01 \\
Col & $14.2 \pm 1.7$ & «0.01 \\
Valley & $10.5 \pm 1.4$ & «0.01 \\
Cirque & $8.8 \pm 0.8$ & N/A \\
\hline
\end{tabular}

Table 2. Attributes (including ELA estimates) of reconstructed Younger Dryas glaciers in the Mournes.

\begin{tabular}{|c|c|c|c|c|c|c|c|}
\hline $\begin{array}{l}\text { Glacier } \\
\text { number }\end{array}$ & $\begin{array}{l}\text { Glacier/Cirque } \\
\text { name }\end{array}$ & $\begin{array}{l}\text { Lat } \\
\left({ }^{\circ} \mathrm{N}\right)\end{array}$ & $\begin{array}{l}\text { Lon } \\
\left({ }^{\circ} \mathrm{W}\right)\end{array}$ & $\begin{array}{l}\text { Area } \\
\min / \max \\
\left(\mathrm{km}^{2}\right)\end{array}$ & $\begin{array}{l}Z_{\min } \\
\min / \max \\
\text { (m.a.s.1.) }\end{array}$ & $\begin{array}{l}Z_{\max } \\
\min / \max \\
\text { (m.a.s.l.) }\end{array}$ & $\begin{array}{l}\text { ELA (AABR: } \\
1.9 \pm 0.81) \\
\text { (m.a.s.l.) }\end{array}$ \\
\hline 1 & Shanlieve & 54.121 & 6.088 & $0.18 / 0.52$ & $287 / 217$ & $476 / 478$ & $356 \pm 33$ \\
\hline 2 & $\begin{array}{l}\text { Eagle Mountain } \\
(\min / \max )\end{array}$ & 54.136 & 6.089 & $0.05 / 0.10$ & $348 / 320$ & $503 / 507$ & $403 \pm 9$ \\
\hline 3 & Slieve Muck & 54.153 & 6.037 & $0.20 / 0.37$ & $405 / 331$ & $592 / 611$ & $483 \pm 30$ \\
\hline 4 & $\begin{array}{l}\text { Carn Mountain } \\
(\min / \max )\end{array}$ & 54.162 & 6.033 & $0.10 / 0.23$ & $451 / 410$ & $604 / 612$ & $524 \pm 14$ \\
\hline 5 & Lough Shannagh & 54.170 & 6.018 & 0.39 & 408 & 561 & $471 \pm 8$ \\
\hline 6 & OTT Mountain & 54.176 & 6.024 & 0.07 & 440 & 551 & $507 \pm 5$ \\
\hline 7 & Slieve Meelbeg & 54.187 & 6.006 & $0.07 / 0.11$ & $485 / 449$ & $617 / 618$ & $546 \pm 19$ \\
\hline 8 & Pollaphuca & 54.189 & 5.994 & $0.12 / 0.15$ & $404 / 403$ & $666 / 668$ & $523 \pm 25$ \\
\hline 9 & Hare's Gap North & 54.192 & 5.976 & 0.08 & 335 & 450 & $398 \pm 6$ \\
\hline 10 & Hare's Gap South & 54.191 & 5.967 & $0.13 / 0.19$ & $383 / 362$ & $536 / 543$ & $456 \pm 10$ \\
\hline 11 & Spinkwee Valley & 54.194 & 5.954 & 0.21 & 331 & 536 & $430 \pm 12$ \\
\hline 12 & Pot of Legawherry & 54.191 & 5.946 & $0.11 / 0.17$ & $458 / 420$ & $653 / 659$ & $546 \pm 14$ \\
\hline 13 & Shan Slieve & 54.193 & 5.941 & $0.03 / 0.06$ & $515 / 476$ & $624 / 626$ & $563 \pm 16$ \\
\hline 14 & Pot of Pulgrave & 54.192 & 5.934 & 0.05 & 503 & 664 & $570 \pm 9$ \\
\hline
\end{tabular}




\begin{tabular}{|c|c|c|c|c|c|c|c|}
\hline 15 & $\begin{array}{l}\text { Glen } \\
(\min / \max )\end{array}$ & 54.185 & 5.930 & $0.11 / 0.15$ & $427 / 408$ & $585 / 590$ & $498 \pm 14$ \\
\hline 16 & $\begin{array}{l}\text { Eagle } \\
(\min / \max )\end{array}$ & 54.188 & 5.919 & $0.11 / 0.16$ & $414 / 410$ & $664 / 668$ & $506 \pm 15$ \\
\hline 17 & Thomas' Mountain & 54.189 & 5.910 & 0.14 & 433 & 597 & $524 \pm 9$ \\
\hline 18 & $\begin{array}{l}\text { Crossone } \\
(\min / \max )\end{array}$ & 54.182 & 5.905 & $0.25 / 0.37$ & $362 / 339$ & $578 / 591$ & $465 \pm 16$ \\
\hline 19 & $\begin{array}{l}\text { Chimney } \\
\text { Mountain } \\
\text { (min/max) }\end{array}$ & 54.167 & 5.914 & $0.14 / 0.20$ & $437 / 380$ & $668 / 669$ & $539 \pm 36$ \\
\hline 20 & Rocky Mountain & 54.162 & 5.926 & 0.29 & 386 & 530 & $468 \pm 6$ \\
\hline 21 & $\begin{array}{l}\text { Castles of } \\
\text { Commedagh }\end{array}$ & 54.180 & 5.939 & 0.16 & 400 & 548 & $478 \pm 7$ \\
\hline 22 & $\begin{array}{ll}\text { Cove } & \text { Lough } \\
(\min / \max ) & \end{array}$ & 54.172 & 5.956 & $0.12 / 0.37$ & $446 / 436$ & $600 / 629$ & $530 \pm 16$ \\
\hline 23 & Slievelamagan & 54.166 & 5.961 & $0.07 / 0.16$ & $466 / 389$ & $699 / 700$ & $528 \pm 63$ \\
\hline 24 & $\begin{array}{l}\text { Binnian Lough } \\
\text { Mean }\end{array}$ & 54.150 & 5.977 & 0.24 & 453 & 649 & $\begin{array}{l}544 \pm 10 \\
\mathbf{4 7 5} \pm \mathbf{3 6}\end{array}$ \\
\hline
\end{tabular}

Table 3. Reconstructed annual accumulation in the Mournes during the Younger Dryas, based on a mean 'climatic' ELA estimate from reconstructed glaciers. Accumulation estimates are calculated using a degree-day model (see section 3.5).

\begin{tabular}{llll}
\hline Mean 'climatic' ELA (m.a.s.l.) & Lapse rate $\left({ }^{\circ} \mathrm{C} \mathrm{m}^{-1}\right)$ & $\mathrm{DDF}\left(\mathrm{mm}^{\circ} \mathrm{C}^{-1} \mathrm{day}^{-1}\right)$ & Accumulation at ELA $\left(\mathrm{mm} \mathrm{a}^{-1}\right)$ \\
\hline $529 \pm 4$ & 0.006 & 2.6 & $984 \pm 6$ \\
$529 \pm 4$ & 0.007 & 2.6 & $851 \pm 7$ \\
$529 \pm 4$ & 0.006 & 4.1 & $1551 \pm 10$ \\
$529 \pm 4$ & 0.007 & 4.1 & $1343 \pm 11$ \\
$529 \pm 4$ & 0.006 & 5.6 & $2119 \pm 13$ \\
$529 \pm 4$ & 0.007 & 5.6 & $1834 \pm 24$ \\
\hline
\end{tabular}

\section{Supplementary information}

Supp 1. Schmidt hammer data from the Mourne Mountains. R-values, age estimates, and their uncertainties represent the mean and mean absolute deviation of 30 measurements per sample site. Numbered locations are shown in Fig. 1A.

\begin{tabular}{|c|c|c|c|c|c|c|c|c|c|c|c|}
\hline $\begin{array}{l}\text { Locatio } \\
\mathrm{n} \\
\text { number }\end{array}$ & $\begin{array}{l}\text { Location } \\
\text { classificatio } \\
\mathrm{n}\end{array}$ & $\begin{array}{l}\text { Sampl } \\
\mathrm{e}\end{array}$ & $\begin{array}{l}\text { Latitud } \\
\text { e }\left({ }^{\circ} \mathrm{N}\right)\end{array}$ & $\begin{array}{l}\text { Longitud } \\
\text { e }\left({ }^{\circ} \mathrm{W}\right)\end{array}$ & $\begin{array}{l}\text { Sampl } \\
\text { e type }\end{array}$ & $\begin{array}{l}\text { Altitud } \\
\mathrm{e} \\
\text { (m.a.s.l } \\
. \text {.) }\end{array}$ & $\begin{array}{l}\text { R- } \\
\text { valu } \\
\text { e }\end{array}$ & $\begin{array}{l}\text { R-value } \\
\text { Uncertaint } \\
\text { y }\end{array}$ & $\begin{array}{l}\mathrm{Ag} \\
\mathrm{e} \\
(\mathrm{ka} \\
)^{2}\end{array}$ & $\begin{array}{l}\text { Age } \\
\text { uncertaint } \\
\text { y } \\
\text { calibratio } \\
\mathrm{n} \text { curve } \\
\text { (ka) }\end{array}$ & $\begin{array}{l}\text { Total } \\
\text { Uncertainty } \\
\text { propagated } \\
\text { quadraticall } \\
\text { y (ka) }\end{array}$ \\
\hline 1 & Cirque & 1 & $\begin{array}{r}54.169 \\
6\end{array}$ & 5.9124 & $\begin{array}{l}\text { Boulde } \\
r\end{array}$ & 415 & 56.1 & 1.6 & 7.5 & 1.60 & 1.61 \\
\hline \multirow{5}{*}{2} & \multirow{5}{*}{ Cirque } & 2 & $\begin{array}{r}54.169 \\
3\end{array}$ & 5.9124 & $\begin{array}{l}\text { Boulde } \\
r\end{array}$ & 423 & 54.2 & 1.7 & 8.4 & 1.60 & 1.62 \\
\hline & & 3 & $\begin{array}{r}54.168 \\
6\end{array}$ & 5.9122 & $\begin{array}{l}\text { Boulde } \\
r\end{array}$ & 449 & 56.7 & 1.9 & 7.2 & 1.60 & 1.61 \\
\hline & & 1 & $\begin{array}{r}54.121 \\
7\end{array}$ & 6.0869 & $\begin{array}{l}\text { Boulde } \\
r\end{array}$ & 303 & 54.6 & 1.7 & 8.2 & 1.60 & 1.62 \\
\hline & & 2 & $\begin{array}{r}54.121 \\
5\end{array}$ & 6.0866 & $\begin{array}{l}\text { Boulde } \\
\mathrm{r}\end{array}$ & 297 & 56.5 & 1.6 & 7.2 & 1.60 & 1.61 \\
\hline & & 3 & $\begin{array}{r}54.121 \\
6\end{array}$ & 6.0865 & $\begin{array}{l}\text { Boulde } \\
r\end{array}$ & 296 & 55.5 & 1.7 & 7.7 & 1.60 & 1.61 \\
\hline 3 & Cirque & 1 & $\begin{array}{r}54.151 \\
8\end{array}$ & 5.9721 & $\begin{array}{l}\text { Boulde } \\
\mathrm{r}\end{array}$ & 454 & 57.3 & 2 & 6.9 & 1.60 & 1.61 \\
\hline
\end{tabular}




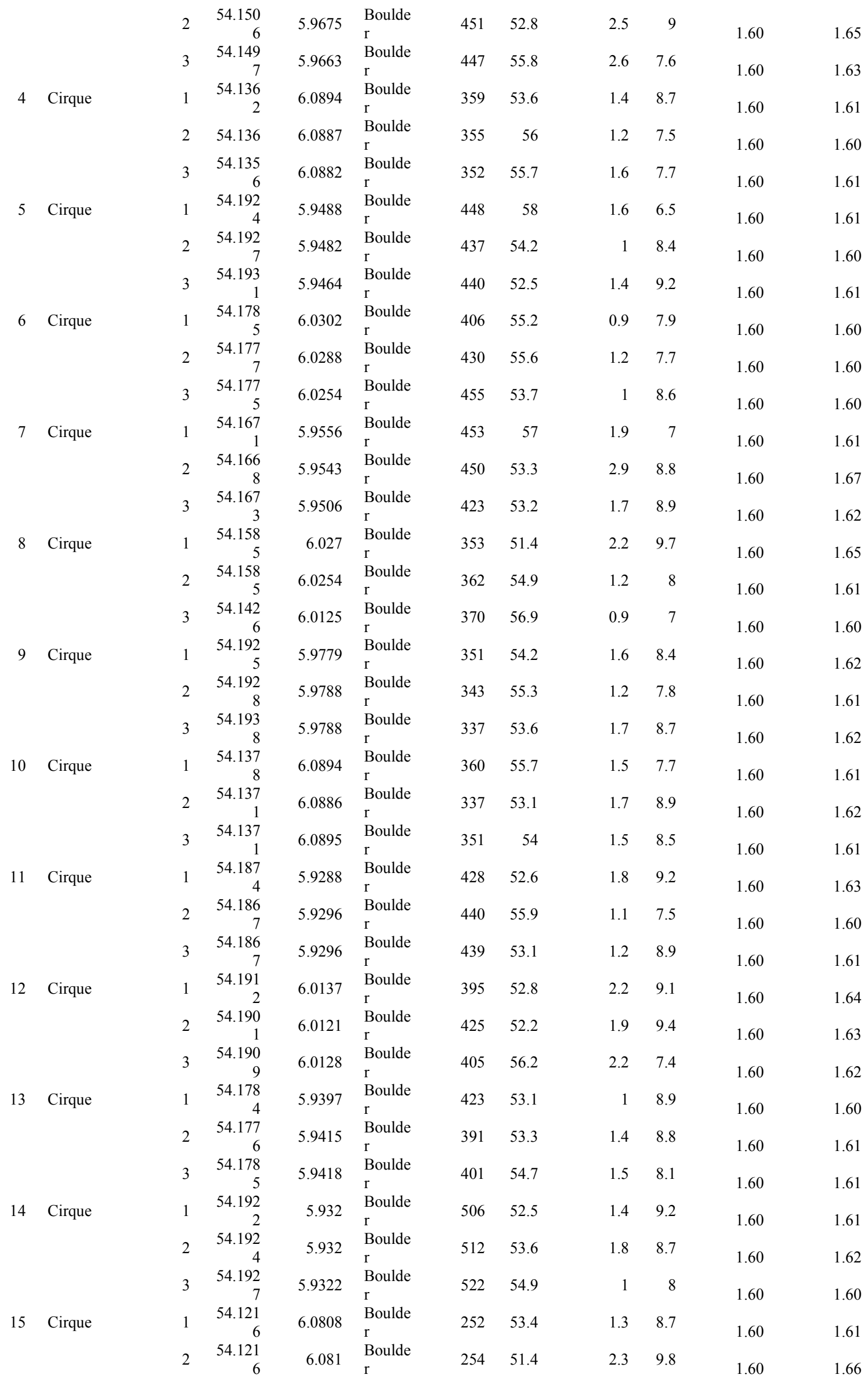




\begin{tabular}{|c|c|c|c|c|c|c|c|c|c|c|c|}
\hline & & 3 & $\begin{array}{r}54.121 \\
3\end{array}$ & 6.0811 & $\begin{array}{l}\text { Boulde } \\
\mathrm{r}\end{array}$ & 258 & 55.5 & 0.9 & 7.7 & 1.60 & 1.60 \\
\hline \multirow[t]{3}{*}{16} & Col & 1 & $\begin{array}{r}54.154 \\
3\end{array}$ & 6.1093 & $\begin{array}{l}\text { Boulde } \\
\mathrm{r}\end{array}$ & 348 & 51.9 & 1.5 & 9.5 & 1.60 & 1.62 \\
\hline & & 2 & $\begin{array}{r}54.155 \\
3\end{array}$ & 6.1085 & $\begin{array}{l}\text { Boulde } \\
\mathrm{r}\end{array}$ & 349 & 56.9 & 1.2 & 7.1 & 1.60 & 1.60 \\
\hline & & 3 & $\begin{array}{r}54.155 \\
5\end{array}$ & 6.1079 & $\begin{array}{l}\text { Boulde } \\
\mathrm{r}\end{array}$ & 351 & 51.5 & 1.3 & 9.7 & 1.60 & 1.61 \\
\hline \multirow[t]{3}{*}{17} & Valley & 1 & $\begin{array}{r}54.182 \\
8\end{array}$ & 6.0372 & $\begin{array}{l}\text { Boulde } \\
\mathrm{r}\end{array}$ & 382 & 54.7 & 2.1 & 8.1 & 1.60 & 1.63 \\
\hline & & 2 & $\begin{array}{r}54.181 \\
6\end{array}$ & 6.0377 & $\begin{array}{l}\text { Boulde } \\
\mathrm{r}\end{array}$ & 410 & 53.2 & 3 & 8.9 & 1.60 & 1.67 \\
\hline & & 3 & $\begin{array}{r}54.180 \\
7\end{array}$ & 6.0343 & $\begin{array}{l}\text { Boulde } \\
\mathrm{r}\end{array}$ & 385 & 51.7 & 1.3 & 9.6 & 1.60 & 1.61 \\
\hline \multirow[t]{3}{*}{18} & Cirque & 1 & $\begin{array}{r}54.152 \\
3\end{array}$ & 6.0359 & $\begin{array}{l}\text { Boulde } \\
\mathrm{r}\end{array}$ & 422 & 50.5 & 1.1 & $\begin{array}{r}10 . \\
2\end{array}$ & 1.60 & 1.61 \\
\hline & & 2 & $\begin{array}{r}54.152 \\
2\end{array}$ & 6.036 & $\begin{array}{l}\text { Boulde } \\
\mathrm{r}\end{array}$ & 426 & 52.2 & 1.4 & 9.4 & 1.60 & 1.62 \\
\hline & & 3 & $\begin{array}{r}54.152 \\
2\end{array}$ & 6.0356 & $\begin{array}{l}\text { Boulde } \\
\mathrm{r}\end{array}$ & 418 & 55.9 & 1.3 & 7.6 & 1.60 & 1.61 \\
\hline \multirow[t]{3}{*}{19} & Valley & 1 & $\begin{array}{r}54.147 \\
5\end{array}$ & 6.0343 & $\begin{array}{l}\text { Boulde } \\
\mathrm{r}\end{array}$ & 338 & 51.3 & 1.8 & 9.8 & 1.60 & 1.63 \\
\hline & & 2 & $\begin{array}{r}54.147 \\
1\end{array}$ & 6.0337 & $\begin{array}{l}\text { Boulde } \\
\mathrm{r}\end{array}$ & 331 & 56.3 & 2 & 7.3 & 1.60 & 1.62 \\
\hline & & 3 & $\begin{array}{r}54.147 \\
2\end{array}$ & 6.0348 & $\begin{array}{l}\text { Boulde } \\
\mathrm{r}\end{array}$ & 335 & 50.5 & 1.4 & $\begin{array}{r}10 . \\
2\end{array}$ & 1.60 & 1.62 \\
\hline \multirow[t]{3}{*}{20} & Col & 1 & $\begin{array}{r}54.147 \\
6\end{array}$ & 6.0941 & $\begin{array}{l}\text { Surfac } \\
\mathrm{e}\end{array}$ & 404 & 50.9 & 1.3 & 10 & 1.60 & 1.62 \\
\hline & & 2 & $\begin{array}{r}54.147 \\
7\end{array}$ & 6.093 & $\begin{array}{l}\text { Surfac } \\
\mathrm{e}\end{array}$ & 411 & 56.3 & 1.7 & 7.4 & 1.60 & 1.61 \\
\hline & & 3 & $\begin{array}{r}54.147 \\
6\end{array}$ & 6.0926 & $\begin{array}{l}\text { Surfac } \\
\mathrm{e}\end{array}$ & 412 & 50.9 & 1.3 & 10 & 1.60 & 1.62 \\
\hline \multirow[t]{3}{*}{21} & Cirque & 1 & 54.191 & 5.9891 & $\begin{array}{l}\text { Boulde } \\
\mathrm{r}\end{array}$ & 398 & 53.8 & 2.2 & 8.6 & 1.60 & 1.63 \\
\hline & & 2 & $\begin{array}{r}54.191 \\
7\end{array}$ & 5.9887 & $\begin{array}{l}\text { Boulde } \\
\mathrm{r}\end{array}$ & 384 & 44.8 & 1.5 & 13 & 1.52 & 1.59 \\
\hline & & 3 & $\begin{array}{r}54.191 \\
7\end{array}$ & 5.9886 & $\begin{array}{l}\text { Boulde } \\
\mathrm{r}\end{array}$ & 357 & 57.8 & 1.3 & 6.6 & 1.60 & 1.60 \\
\hline \multirow[t]{3}{*}{22} & Summit & 1 & $\begin{array}{r}54.149 \\
6\end{array}$ & 6.1123 & $\begin{array}{l}\text { Surfac } \\
\mathrm{e}\end{array}$ & 438 & 51.9 & 1.3 & 9.5 & 1.60 & 1.61 \\
\hline & & 2 & $\begin{array}{r}54.149 \\
9\end{array}$ & 6.1122 & $\begin{array}{l}\text { Surfac } \\
\text { e }\end{array}$ & 437 & 53.2 & 1.2 & 8.9 & 1.60 & 1.61 \\
\hline & & 3 & 54.15 & 6.1122 & $\begin{array}{l}\text { Surfac } \\
\text { e }\end{array}$ & 436 & 51.2 & 1.6 & 9.8 & 1.60 & 1.63 \\
\hline \multirow[t]{3}{*}{23} & Valley & 1 & 54.16 & 6.1169 & $\begin{array}{l}\text { Boulde } \\
\mathrm{r}\end{array}$ & 262 & 51.7 & 1.2 & 9.6 & 1.60 & 1.61 \\
\hline & & 2 & $\begin{array}{r}54.159 \\
8\end{array}$ & 6.1182 & $\begin{array}{l}\text { Boulde } \\
\text { r }\end{array}$ & 266 & 53.1 & 1.7 & 8.9 & 1.60 & 1.62 \\
\hline & & 3 & $\begin{array}{r}54.160 \\
2\end{array}$ & 6.1164 & $\begin{array}{l}\text { Boulde } \\
\mathrm{r}\end{array}$ & 267 & 51.1 & 1.2 & 9.9 & 1.60 & 1.61 \\
\hline \multirow[t]{3}{*}{24} & Valley & 1 & $\begin{array}{r}54.131 \\
7\end{array}$ & 6.0786 & $\begin{array}{l}\text { Boulde } \\
\mathrm{r}\end{array}$ & 212 & 52 & 1.3 & 9.5 & 1.60 & 1.61 \\
\hline & & 2 & $\begin{array}{r}54.132 \\
2\end{array}$ & 6.0776 & $\begin{array}{l}\text { Boulde } \\
\mathrm{r}\end{array}$ & 201 & 52.4 & 1.7 & 9.3 & 1.60 & 1.62 \\
\hline & & 3 & $\begin{array}{r}54.132 \\
2\end{array}$ & 6.0774 & $\begin{array}{l}\text { Boulde } \\
\mathrm{r}\end{array}$ & 202 & 48.9 & 1.3 & 11 & 1.53 & 1.55 \\
\hline \multirow[t]{3}{*}{25} & Valley & 1 & $\begin{array}{r}54.144 \\
7\end{array}$ & 6.0246 & $\begin{array}{l}\text { Boulde } \\
\mathrm{r}\end{array}$ & 269 & 50.3 & 1.3 & $\begin{array}{r}10 . \\
3\end{array}$ & 1.60 & 1.62 \\
\hline & & 2 & $\begin{array}{r}54.145 \\
1\end{array}$ & 6.0241 & $\begin{array}{l}\text { Boulde } \\
\mathrm{r}\end{array}$ & 266 & 52.7 & 1.8 & 9.1 & 1.60 & 1.63 \\
\hline & & 3 & $\begin{array}{r}54.145 \\
7\end{array}$ & 6.0234 & $\begin{array}{l}\text { Boulde } \\
\mathrm{r}\end{array}$ & 274 & 48.5 & 1.6 & $\begin{array}{r}11 . \\
2\end{array}$ & 1.57 & 1.61 \\
\hline \multirow[t]{3}{*}{26} & Summit & 1 & $\begin{array}{r}54.121 \\
6\end{array}$ & 6.0935 & $\begin{array}{l}\text { Boulde } \\
\mathrm{r}\end{array}$ & 486 & 51.6 & 1.8 & 9.6 & 1.60 & 1.63 \\
\hline & & 2 & $\begin{array}{r}54.121 \\
6\end{array}$ & 6.0937 & $\begin{array}{l}\text { Boulde } \\
\mathrm{r}\end{array}$ & 488 & 50.8 & 1.6 & 10 & 1.60 & 1.63 \\
\hline & & 3 & $\begin{array}{r}54.121 \\
5\end{array}$ & 6.0937 & $\begin{array}{l}\text { Boulde } \\
\mathrm{r}\end{array}$ & 489 & 49 & 1.8 & $\begin{array}{r}10 . \\
9\end{array}$ & 1.58 & 1.63 \\
\hline \multirow[t]{3}{*}{27} & Col & 1 & $\begin{array}{r}54.173 \\
7\end{array}$ & 6.0228 & $\begin{array}{l}\text { Surfac } \\
\mathrm{e}\end{array}$ & 514 & 55.3 & 1.2 & 7.9 & 1.60 & 1.61 \\
\hline & & 2 & $\begin{array}{r}54.174 \\
2\end{array}$ & 6.0222 & $\begin{array}{l}\text { Boulde } \\
\mathrm{r}\end{array}$ & 510 & 49.6 & 1.4 & $\begin{array}{r}10 . \\
6\end{array}$ & 1.59 & 1.61 \\
\hline & & 3 & $\begin{array}{r}54.174 \\
1\end{array}$ & 6.022 & $\begin{array}{l}\text { Boulde } \\
\mathrm{r}\end{array}$ & 511 & 46.4 & 3.4 & $\begin{array}{r}12 . \\
2\end{array}$ & 1.54 & 1.78 \\
\hline
\end{tabular}




\begin{tabular}{|c|c|c|c|c|c|c|c|c|c|c|c|}
\hline \multirow[t]{3}{*}{28} & \multirow[t]{3}{*}{ Valley } & 1 & $\begin{array}{r}54.194 \\
7\end{array}$ & 5.9173 & $\begin{array}{l}\text { Boulde } \\
\mathrm{r}\end{array}$ & 287 & 49.4 & 4.1 & $\begin{array}{r}10 . \\
7\end{array}$ & 1.58 & 1.82 \\
\hline & & 2 & $\begin{array}{r}54.192 \\
7\end{array}$ & 5.9217 & $\begin{array}{l}\text { Boulde } \\
\mathrm{r}\end{array}$ & 308 & 48.3 & 2.1 & $\begin{array}{r}11 . \\
3\end{array}$ & 1.57 & 1.64 \\
\hline & & 3 & 54.192 & 5.9216 & $\begin{array}{l}\text { Boulde } \\
\mathrm{r}\end{array}$ & 315 & 52.8 & 1.3 & 9.1 & 1.60 & 1.61 \\
\hline \multirow[t]{3}{*}{29} & \multirow[t]{3}{*}{ Valley } & 1 & $\begin{array}{r}54.158 \\
7\end{array}$ & 5.9731 & $\begin{array}{l}\text { Boulde } \\
\text { r }\end{array}$ & 352 & 52.3 & 1.7 & 9.3 & 1.60 & 1.62 \\
\hline & & 2 & $\begin{array}{r}54.157 \\
7\end{array}$ & 5.9648 & $\begin{array}{l}\text { Boulde } \\
\mathrm{r}\end{array}$ & 341 & 49.7 & 2 & $\begin{array}{r}10 . \\
6\end{array}$ & 1.59 & 1.64 \\
\hline & & 3 & $\begin{array}{r}54.157 \\
9\end{array}$ & 5.9618 & $\begin{array}{l}\text { Boulde } \\
\mathrm{r}\end{array}$ & 337 & 47.5 & 2.1 & $\begin{array}{r}11 . \\
6\end{array}$ & 1.56 & 1.64 \\
\hline \multirow[t]{3}{*}{30} & \multirow[t]{3}{*}{ Valley } & 1 & $\begin{array}{r}54.156 \\
6\end{array}$ & 5.9586 & $\begin{array}{l}\text { Boulde } \\
\mathrm{r}\end{array}$ & 295 & 49.9 & 2 & $\begin{array}{r}10 . \\
5\end{array}$ & 1.59 & 1.65 \\
\hline & & 2 & $\begin{array}{r}54.156 \\
6\end{array}$ & 5.9585 & $\begin{array}{l}\text { Boulde } \\
\mathrm{r}\end{array}$ & 294 & 49.3 & 1.9 & $\begin{array}{r}10 . \\
8\end{array}$ & 1.58 & 1.64 \\
\hline & & 3 & $\begin{array}{r}54.156 \\
4\end{array}$ & 5.9585 & $\begin{array}{l}\text { Boulde } \\
\mathrm{r}\end{array}$ & 293 & 47.5 & 2.2 & $\begin{array}{r}11 . \\
6\end{array}$ & 1.56 & 1.65 \\
\hline \multirow[t]{3}{*}{31} & \multirow[t]{3}{*}{ Valley } & 1 & $\begin{array}{r}54.171 \\
8\end{array}$ & 5.8921 & $\begin{array}{l}\text { Boulde } \\
\mathrm{r}\end{array}$ & 211 & 52.1 & 1.7 & 9.4 & 1.60 & 1.63 \\
\hline & & 2 & 54.172 & 5.8925 & $\begin{array}{l}\text { Boulde } \\
\mathrm{r}\end{array}$ & 209 & 49.4 & 2 & $\begin{array}{r}10 . \\
7\end{array}$ & 1.58 & 1.64 \\
\hline & & 3 & $\begin{array}{r}54.171 \\
8\end{array}$ & 5.8927 & $\begin{array}{l}\text { Boulde } \\
\mathrm{r}\end{array}$ & 216 & 45.1 & 1.5 & $\begin{array}{r}12 . \\
8\end{array}$ & 1.53 & 1.59 \\
\hline \multirow[t]{3}{*}{32} & \multirow[t]{3}{*}{ Cirque } & 1 & $\begin{array}{r}54.167 \\
9\end{array}$ & 6.0143 & $\begin{array}{l}\text { Boulde } \\
\mathrm{r}\end{array}$ & 413 & 51.6 & 1.9 & 9.6 & 1.60 & 1.63 \\
\hline & & 2 & $\begin{array}{r}54.166 \\
2\end{array}$ & 6.0164 & $\begin{array}{l}\text { Boulde } \\
\mathrm{r}\end{array}$ & 418 & 53.3 & 1.2 & 8.8 & 1.60 & 1.61 \\
\hline & & 3 & $\begin{array}{r}54.164 \\
1\end{array}$ & 6.0196 & $\begin{array}{l}\text { Boulde } \\
\mathrm{r}\end{array}$ & 413 & 39.9 & 1.4 & $\begin{array}{r}15 . \\
3\end{array}$ & 1.50 & 1.59 \\
\hline \multirow[t]{3}{*}{33} & \multirow[t]{3}{*}{ Summit } & 1 & $\begin{array}{r}54.189 \\
5\end{array}$ & 6.0009 & $\begin{array}{l}\text { Boulde } \\
\mathrm{r}\end{array}$ & 685 & 53.9 & 2.3 & 8.5 & 1.60 & 1.64 \\
\hline & & 2 & $\begin{array}{r}54.190 \\
3\end{array}$ & 6.001 & $\begin{array}{l}\text { Boulde } \\
\mathrm{r}\end{array}$ & 675 & 49 & 2.8 & $\begin{array}{r}10 . \\
9\end{array}$ & 1.58 & 1.70 \\
\hline & & 3 & $\begin{array}{r}54.191 \\
3\end{array}$ & 6.0004 & $\begin{array}{l}\text { Boulde } \\
\mathrm{r}\end{array}$ & 681 & 40.9 & 3 & $\begin{array}{r}14 . \\
9\end{array}$ & 1.50 & 1.86 \\
\hline \multirow[t]{3}{*}{34} & \multirow[t]{3}{*}{ Col } & 1 & $\begin{array}{r}54.190 \\
3\end{array}$ & 5.9731 & Bouler & 441 & 43.6 & 3.1 & $\begin{array}{r}13 . \\
5\end{array}$ & 1.51 & 1.79 \\
\hline & & 2 & $\begin{array}{r}54.190 \\
3\end{array}$ & 5.9734 & Bouler & 443 & 48.4 & 1.4 & $\begin{array}{r}11 . \\
2\end{array}$ & 1.57 & 1.60 \\
\hline & & 3 & $\begin{array}{r}54.190 \\
3\end{array}$ & 5.9735 & Bouler & 441 & 51.4 & 1.3 & 9.8 & 1.60 & 1.62 \\
\hline \multirow[t]{3}{*}{35} & \multirow[t]{3}{*}{ Valley } & 1 & $\begin{array}{r}54.195 \\
4\end{array}$ & 6.0184 & $\begin{array}{l}\text { Boulde } \\
\mathrm{r}\end{array}$ & 330 & 48.7 & 2.8 & $\begin{array}{r}11 . \\
1\end{array}$ & 1.57 & 1.70 \\
\hline & & 2 & $\begin{array}{r}54.195 \\
4\end{array}$ & 6.0184 & $\begin{array}{l}\text { Boulde } \\
\mathrm{r}\end{array}$ & 332 & 47.5 & 2.1 & $\begin{array}{r}11 . \\
6\end{array}$ & 1.56 & 1.64 \\
\hline & & 3 & $\begin{array}{r}54.195 \\
4\end{array}$ & 6.0183 & $\begin{array}{l}\text { Boulde } \\
\mathrm{r}\end{array}$ & 333 & 43.4 & 2.2 & $\begin{array}{r}13 . \\
6\end{array}$ & 1.51 & 1.66 \\
\hline \multirow[t]{3}{*}{36} & \multirow[t]{3}{*}{ Cirque } & 1 & $\begin{array}{r}54.189 \\
8\end{array}$ & 5.929 & $\begin{array}{l}\text { Boulde } \\
\mathrm{r}\end{array}$ & 377 & 42.9 & 1.5 & $\begin{array}{r}13 . \\
9\end{array}$ & 1.51 & 1.59 \\
\hline & & 2 & $\begin{array}{r}54.188 \\
5\end{array}$ & 5.9282 & $\begin{array}{l}\text { Boulde } \\
\mathrm{r}\end{array}$ & 403 & 41.9 & 2.1 & $\begin{array}{r}14 . \\
4\end{array}$ & 1.50 & 1.67 \\
\hline & & 3 & $\begin{array}{r}54.188 \\
2\end{array}$ & 5.9278 & $\begin{array}{l}\text { Boulde } \\
\mathrm{r}\end{array}$ & 414 & 54.4 & 1.8 & 8.3 & 1.60 & 1.62 \\
\hline \multirow[t]{3}{*}{37} & \multirow[t]{3}{*}{ Summit } & 1 & $\begin{array}{r}54.140 \\
4\end{array}$ & 5.971 & $\begin{array}{l}\text { Surfac } \\
\mathrm{e}\end{array}$ & 648 & 44.7 & 1.6 & 13 & 1.52 & 1.59 \\
\hline & & 2 & $\begin{array}{r}54.140 \\
4\end{array}$ & 5.9709 & $\begin{array}{l}\text { Surfac } \\
\text { e }\end{array}$ & 648 & 45.4 & 1.5 & $\begin{array}{r}12 . \\
7\end{array}$ & 1.53 & 1.59 \\
\hline & & 3 & $\begin{array}{r}54.140 \\
3\end{array}$ & 5.9709 & $\begin{array}{l}\text { Surfac } \\
\text { e }\end{array}$ & 649 & 49.1 & 2.1 & $\begin{array}{r}10 . \\
9\end{array}$ & 1.58 & 1.65 \\
\hline \multirow[t]{3}{*}{38} & \multirow[t]{3}{*}{$\mathrm{Col}$} & 1 & $\begin{array}{r}54.172 \\
2\end{array}$ & 5.9258 & Bouler & 529 & 46.3 & 2.3 & $\begin{array}{r}12 . \\
2\end{array}$ & 1.54 & 1.66 \\
\hline & & 2 & $\begin{array}{r}54.172 \\
9\end{array}$ & 5.927 & Bouler & 544 & 47.5 & 1.7 & $\begin{array}{r}11 . \\
6\end{array}$ & 1.56 & 1.61 \\
\hline & & 3 & $\begin{array}{r}54.172 \\
6\end{array}$ & 5.9282 & Bouler & 538 & 44.9 & 1.2 & $\begin{array}{r}12 . \\
9\end{array}$ & 1.53 & 1.56 \\
\hline \multirow[t]{3}{*}{39} & \multirow[t]{3}{*}{ Valley } & 1 & 54.136 & 6.0321 & $\begin{array}{l}\text { Boulde } \\
\mathrm{r}\end{array}$ & 225 & 42.7 & 2.1 & 14 & 1.51 & 1.66 \\
\hline & & 2 & 54.136 & 6.032 & $\begin{array}{l}\text { Boulde } \\
\mathrm{r}\end{array}$ & 224 & 48.6 & 1.2 & $\begin{array}{r}11 . \\
1\end{array}$ & 1.57 & 1.59 \\
\hline & & 3 & $\begin{array}{r}54.136 \\
1\end{array}$ & 6.0331 & $\begin{array}{l}\text { Boulde } \\
\mathrm{r}\end{array}$ & 211 & 42.5 & 1.1 & $\begin{array}{r}14 . \\
1\end{array}$ & 1.51 & 1.55 \\
\hline 40 & Summit & 1 & $\begin{array}{r}54.167 \\
6\end{array}$ & 5.919 & $\begin{array}{l}\text { Surfac } \\
\mathrm{e}\end{array}$ & 604 & 41.9 & 1.5 & $\begin{array}{r}14 . \\
4\end{array}$ & 1.50 & 1.59 \\
\hline
\end{tabular}




\begin{tabular}{|c|c|c|c|c|c|c|c|c|c|c|c|}
\hline & & 2 & 54.167 & 5.919 & Surfac & 614 & 47.1 & 2 & 11. & 155 & 163 \\
\hline & & & 54.167 & & Surfac & & & & 14. & (.J) & $1.0 J$ \\
\hline & & 3 & 4 & 5.9196 & & 610 & 41.8 & 1.9 & 4 & 1.50 & 1.64 \\
\hline 41 & Col & 1 & 54.186 & 5.9962 & Boulde & 522 & 44.8 & 1.6 & 12. & 152 & 150 \\
\hline & & & $\begin{aligned} 1 \\
54.185\end{aligned}$ & & $\begin{array}{l}\mathrm{r} \\
\text { Boulde }\end{array}$ & & & & 13. & 1.52 & 1.59 \\
\hline & & 2 & & 5.996 & & 517 & 43.7 & 2.2 & 5 & 1.52 & 1.66 \\
\hline & & 3 & $\begin{array}{r}54.185 \\
9\end{array}$ & 5.9962 & Boulde & 521 & 42 & 1.7 & 14. & 151 & 161 \\
\hline 12 & Summit & 1 & 54.184 & 500 & Surfac & 731 & 421 & 15 & 13. & & \\
\hline 42 & summit & 1 & 8 & 5.99 & $\mathrm{e}$ & 131 & 43.1 & 1.5 & 8 & 1.51 & 1.59 \\
\hline & & 2 & $\begin{array}{r}54.184 \\
8\end{array}$ & 5.9898 & Surfac & 730 & 45 & 1.9 & 12. & 153 & 162 \\
\hline & & 3 & $\begin{array}{r}\circ \\
54.183\end{array}$ & 5080 & Surfac & 728 & 411 & 14 & 14. & נכ. & \\
\hline & & 3 & & 5.909 & e & 120 & 41.1 & 1.4 & 8 & 1.50 & 1.58 \\
\hline 43 & Valley & 1 & $\begin{array}{r}54.139 \\
8\end{array}$ & 5.94 & Boulde & 182 & 39.3 & 0.9 & $\begin{array}{r}15 . \\
6\end{array}$ & 1.50 & 1.54 \\
\hline & & 2 & 54.141 & 5.9439 & Boulde & 204 & 507 & 24 & 10. & & \\
\hline & & & 54.141 & 3.945 & r & & & & 1 & 1.60 & 1.67 \\
\hline & & 3 & $\begin{array}{r}54.141 \\
4\end{array}$ & 5.9468 & $\begin{array}{l}\text { Boulde } \\
\mathrm{r}\end{array}$ & 219 & 36.7 & 1.5 & $\begin{array}{r}16 . \\
9\end{array}$ & 1.50 & 1.65 \\
\hline 44 & Summit & 1 & $\begin{array}{r}54.153 \\
4\end{array}$ & 5.9812 & $\begin{array}{l}\text { Surfac } \\
\mathrm{e}\end{array}$ & 654 & 41.5 & 1.2 & $\begin{array}{r}14 . \\
6\end{array}$ & 1.50 & 1.56 \\
\hline & & 2 & 54.153 & 5.9802 & Surfac & 675 & 45 & 2.5 & 12. & 153 & 160 \\
\hline & & & 54.153 & & $\begin{array}{l}\text { e } \\
\text { Surfac }\end{array}$ & & & & $\begin{array}{r}9 \\
15 .\end{array}$ & 1.33 & 1.69 \\
\hline & & 3 & & 5.9805 & $\mathrm{e}$ & 659 & 39.7 & 1.1 & 5 & 1.50 & 1.56 \\
\hline 45 & Col & 1 & $\begin{array}{r}54.183 \\
9\end{array}$ & 5.9337 & Tor & 576 & 42.6 & 1.7 & 14 & 1.51 & 1.61 \\
\hline & & 2 & $\begin{array}{r}54.183 \\
9\end{array}$ & 5.9337 & Tor & 576 & 41.1 & 1.4 & $\begin{array}{r}14 . \\
8\end{array}$ & 150 & 158 \\
\hline & & 3 & $\begin{array}{r}54.183 \\
9\end{array}$ & 5.9337 & Tor & 575 & 41.1 & 2 & 14. & 150 & 167 \\
\hline & Valley & & 54.202 & & Surfac & & & & & & \\
\hline 46 & Valley & 1 & & 5.9943 & e & 253 & 40.6 & 1.8 & 15 & 1.50 & 1.64 \\
\hline & & 2 & $\begin{array}{r}54.202 \\
8\end{array}$ & 5.9948 & $\begin{array}{l}\text { Surfac } \\
\mathrm{e}\end{array}$ & 258 & 42.6 & 2.3 & 14 & 1.51 & 1.69 \\
\hline & & 3 & $\begin{array}{r}54.202 \\
8\end{array}$ & 5.9947 & $\begin{array}{l}\text { Surfac } \\
\mathrm{e}\end{array}$ & 257 & 40 & 1.9 & $\begin{array}{r}15 . \\
3\end{array}$ & 1.50 & 1.67 \\
\hline 47 & Summit & 1 & 54.136 & 6.1 & Surfac & 592 & 36.4 & 1.1 & 17. & & \\
\hline & & & $\begin{array}{r}3 \\
54136\end{array}$ & & e & & & & 1 & 1.50 & 1.59 \\
\hline & & 2 & $\begin{array}{r}54.136 \\
5\end{array}$ & 6.1003 & $\begin{array}{l}\text { Surfac } \\
\mathrm{e}\end{array}$ & 598 & 40.5 & 1.6 & 15 & 1.50 & 1.61 \\
\hline & & 3 & $\begin{array}{r}54.136 \\
5\end{array}$ & 6.1008 & $\begin{array}{l}\text { Surfac } \\
\mathrm{e}\end{array}$ & 605 & 39.3 & 2.7 & $\begin{array}{r}15 . \\
6\end{array}$ & 1.50 & 1.84 \\
\hline 48 & Summit & 1 & $\begin{array}{r}54.175 \\
6\end{array}$ & 5.9556 & $\begin{array}{l}\text { Surfac } \\
\mathrm{e}\end{array}$ & 623 & 38.5 & 1.4 & 16 & 1.50 & 1.61 \\
\hline & & 2 & 54.175 & 5.9551 & Surfac & 627 & 408 & 17 & 14. & & \\
\hline & & & 7 & 1930נ. & & & & & 9 & 1.50 & 1.62 \\
\hline & & 3 & $\begin{array}{r}54.175 \\
8\end{array}$ & 5.9552 & $\begin{array}{l}\text { Surfac } \\
\mathrm{e}\end{array}$ & 623 & 36.5 & 1.2 & 17 & 1.50 & 1.60 \\
\hline 49 & Summit & 1 & $\begin{array}{r}54.158 \\
8\end{array}$ & 6.0396 & $\begin{array}{l}\text { Boulde } \\
r\end{array}$ & 662 & 38 & 1.6 & $\begin{array}{r}16 . \\
3\end{array}$ & 1.50 & 1.65 \\
\hline & & 2 & 54.158 & 6.0397 & Boulde & 661 & 39.3 & 2.3 & 15. & 150 & 176 \\
\hline & & & 54.158 & & $\begin{array}{l}\mathrm{r} \\
\text { Boulde }\end{array}$ & & & & & 1.50 & 1.76 \\
\hline & & 3 & 6 & 6.04 & $\mathrm{r}$ & 659 & 38.2 & 1.8 & 2 & 1.50 & 1.68 \\
\hline 50 & Summit & 1 & $\begin{array}{r}54.167 \\
3\end{array}$ & 6.029 & $\begin{array}{l}\text { Surfac } \\
\mathrm{e}\end{array}$ & 585 & 37.1 & 1.2 & $\begin{array}{r}16 . \\
7\end{array}$ & 150 & 160 \\
\hline & & 2 & 54.167 & 60780 & Surfac & 507 & 300 & 10 & 15. & & \\
\hline & & 2 & 2 & 6.0289 & $\mathrm{e}$ & 581 & 39.9 & 1.9 & 4 & 1.50 & 1.67 \\
\hline & & 3 & $\begin{array}{r}54.167 \\
7\end{array}$ & 6.03 & $\begin{array}{l}\text { Surfac } \\
\mathrm{e}\end{array}$ & 548 & 38.2 & 1.4 & $\begin{array}{r}16 . \\
2\end{array}$ & 1.50 & 1.61 \\
\hline 51 & Summit & 1 & 54.165 & 5.9662 & Surfac & 670 & 42.2 & 1.8 & 14. & & \\
\hline & & 1 & $\begin{array}{r}1 \\
54.164\end{array}$ & & $\begin{array}{l}\text { e } \\
\text { Surfac }\end{array}$ & & & & $\begin{array}{r}2 \\
16 .\end{array}$ & 1.51 & 1.62 \\
\hline & & 2 & 5 & 5.966 & e & 661 & 37.4 & 1.8 & 6 & 1.50 & 1.70 \\
\hline & & 3 & $\begin{array}{r}54.164 \\
1\end{array}$ & 5.9657 & $\begin{array}{l}\text { Surfac } \\
\mathrm{e}\end{array}$ & 654 & 35.6 & 1.3 & $\begin{array}{r}17 . \\
5\end{array}$ & 1.51 & 1.64 \\
\hline 52 & Summit & 1 & 54.181 & 50201 & Boulde & 825 & 20 & 1 & 16. & & \\
\hline 52 & Summit & 1 & & 5.9201 & $\mathrm{r}$ & 835 & 38.4 & 1.5 & 1 & 1.50 & 1.63 \\
\hline & & 2 & 54.180 & 5.9212 & $\begin{array}{l}\text { Boulde } \\
r\end{array}$ & 846 & 30.9 & 1 & $\begin{array}{r}19 . \\
7\end{array}$ & 1.55 & 68 \\
\hline
\end{tabular}




\begin{tabular}{|c|c|c|c|c|c|c|c|c|c|c|c|}
\hline & \multirow{5}{*}{ summit } & 3 & $\begin{array}{r}54.180 \\
6\end{array}$ & 5.92 & Boulde & 844 & 41.8 & 1.8 & $\begin{array}{r}14 . \\
4\end{array}$ & 1.50 & 1.63 \\
\hline & & 1 & 54.141 & 5.98 & Surfac & 746 & 30.3 & 2 & 20. & 157 & 205 \\
\hline & & & 54.142 & & Surfac & & & & 14. & 1.07 & 2.00 \\
\hline & & 2 & & 3.98 & $\mathrm{e}$ & 141 & 41.4 & 2.3 & 6 & 1.50 & 1.71 \\
\hline & & 3 & $\begin{array}{r}54.144 \\
6\end{array}$ & 5.9795 & $\begin{array}{l}\text { Surfac } \\
\mathrm{e}\end{array}$ & 709 & 37.2 & 2.6 & $\begin{array}{r}16 . \\
7\end{array}$ & 1.50 & 1.90 \\
\hline
\end{tabular}

